\title{
Bibliográfia
}

\section{A 2016-ban megjelent, jog- és államtudományi tárgyú könyvek annotált bibliográfiája 1. rész}

Folyóiratunkban rendszeresen jelenik meg az elmúlt időszak új, hazai szakkönyveiről készült, annotált bibliográfia. Az annotáció a könyv felhasználhatóságáról írott, rövid, tényszerü leírás, amely a bibliográfiai adatok mellett meghatározza a müfajt, illetve röviden körvonalazza a feldolgozott témát és a bemutatott eredményeket is. Folyóiratunk a továbbiakban évente négy lapszámmal jelenik meg, ennek megfelelően az annotációkat két részletben, a második és a negyedik számban közöljük. A mostani számban a 2016-ban megjelent könyvek első részét dolgozzuk fel. Annak megfelelően, hogy a Magyar Tudományos Művek Tára (MTMT) csak a 120 oldal terjedelmet elérő munkákat kezeli önálló kiadványként, az ettől jelentősen elmaradó (90 oldal alatti) kiadványokat nem annotáljuk. A bemutatás jogterületenként történik, a jogterületek elnevezésének, az egyes jogterületeken belül pedig a szerzők (szerkesztők) nevének ábécérendjében következik.

Első lépésként ezúttal is egy listát állítottunk össze különböző intézményi könyvtári katalógusok, a Magyar Országos Közös Katalógus (MOKKA), illetve az Országos Széchényi Könyvtár interneten is közölt adatai alapján. Emellett kiadók honlapján, hírlevelekben, a szerzők publikációs listáiban és saját könyvespolcainkon is kutattunk. Gyűjtőmunkánkat jelentős mértékben segítette a Debreceni Egyetem Egyetemi és Nemzeti Könyvtára (DEENK), amely köteles könyvtárként a hazai kiadványok gyűjtését, feldolgozását, illetve részben - a mienkhez képest némileg eltérő szempontok szerint - annotálását is elvégzi.

A leírások elkészítése során általában a szerzők, kiadók által készített fülszövegeket, ajánlásokat, illetve a kötetekről készült recenziókat is igyekszünk fellelni és hasznosítani. Az annotációk azonban minden esetben úgy készültek, hogy magát az adott könyvet is a kezünkbe vettük, s ehhez, ha kellett, könyvtárközi kölcsönzéssel vagy más intézményekben dolgozó kollégáktól megkértük. Az annotációk tehát önálló feldolgozó munka eredményei.

Tisztában vagyunk azzal, hogy a feldolgozás szempontrendszere legjobb igyekezetünk ellenére is hiányos, illetve a sok szakterület és közreműködő okán egyenetlen. Örömmel veszünk és meg is szívlelünk ezért minden észrevételt, amely munkánkra vonatkozóan szerkesztőségünkhöz beérkezik. Szívesen fogadjuk azt is, ha a szerzők figyelmünkbe ajánlják saját könyvüket. 
A leírások első, rövidebb része tartalmazza a könyvészeti adatokat (cím, szerző/szerkesztő, a kiadó neve, a kiadás helye és éve) az arra való utalással, hogy van-e a könyvben bibliográfia (irodalomjegyzék), illetve hogy a könyv milyen müfajba sorolható be. A terjedelmet oldalszámban adjuk meg, s közöljük a kötet azonosítására szolgáló ISBN-t, illetve sorozatok esetében az ISSN-t is. A második rész röviden leírja az alkotót, illetve alkotókat. Ezt követően (a változatlan utánnyomások kivételével) általában 6-12 sor terjedelemben számba vesszük a mü tárgyköreit, föbb eredményeit. Az eredmények részletes értékelését azonban nem végezzük el (recenziószintủ bemutatást nem végzünk). A sokszerzős, illetve a gyüjteményes munkák esetében nem kerül sor valamennyi szerző név szerinti megemlítésére, $s$ a tanulmányok számától, tematikai egymáshoz kapcsolódásától függ, hogy minden témát megnevezünk-e. A felsőoktatási tananyagok, jogszabályközlések bemutatását a lehető legtömörebben végezzük el. A müfaj sajátosságaiból következően az annotáció nem tekinthető az adott müre történő szakirodalmi hivatkozásnak.

Az annotációk szerzői valamilyen formában kivétel nélkül kapcsolódnak a Debreceni Egyetem Állam- és Jogtudományi Karához, legyen szó munkatársainkról, óraadóinkról vagy jelenlegi és volt hallgatóinkról. Az annotációk végén szereplő monogramok feloldása a következő: Balogh Áron Péter (B. Á. P.) PhD-hallgató, Balogh Éva (B. É.) egyetemi tanársegéd, Balogh Judit (B. J.) egyetemi docens, Balogh Sándor (B. S.) PhD-hallgató, Bányai Orsolya (B. O.) egyetemi adjunktus, Batta Júlia Dóra (B. J. D.) joghallgató, Kovácsné Becánics Adrienn (B. A.) egyetemi tanársegéd, Bihari Erika (B. E.) PhD-hallgató, Bordás Péter (B. P.) egyetemi tanársegéd, Csukás Enikő (Cs. E.) joghallgató, Csürös Gabriella (Cs. G.) egyetemi adjunktus, Deák Izabella (D. I.) kutatási asszisztens, Deák Viktória (D. V.) PhD-hallgató, Falusi Bernadett (F. B.) PhD-hallgató, Ficsor Krisztina (F. K.) egyetemi adjunktus, Fodor László (F. L.) egyetemi tanár, Gábri Angéla (G. A.) PhD-hallgató, Gajdos Martina (G. M.) joghallgató, Hadházi Dávid (H. D.) PhD-hallgató, Jakab Viktória (J. V.) joghallgató, Juhász György (J. Gy.) PhD-hallgató, Kanyuk Petra Ágnes (K. P. Á) joghallgató, Kazsamér Katalin Enikő (K. K. E.) joghallgató, Kőműves Barbara (K. B.) PhD-hallgató, Kristóf Nóra (K. N.) joghallgató, Lovas Dóra (L. D.) PhD-hallgató, Nagy Evelin Éva (N. E. É.) joghallgató, Nagy Nelli (N. N.) joghallgató, Molnár Tamás (M. T.) PhD-hallgató, Muhar Eszter (M. E.) joghallgató, Pápai-Tarr Ágnes (P. T. Á.) egyetemi adjunktus, Sipkáné Puskás Ágnes (P. Á.) PhD-hallgató, Rácz András (R. A.) joghallgató, Sipka Péter (S. P.) egyetemi adjunktus, Sütő Bianka (S. B.) PhD-hallgató, Szabó Zsanett (Sz. Zsa.) PhD-hallgató, Szász Viktória (Sz. V.) PhD hallgató, Szilágyi Dániel (Sz. D.) PhD-hallgató, Szilágyi Zsuzsanna (Sz. Zs.) joghallgató, Varga Judit (V. J.) egyetemi adjunktus, Veszprémi Bernadett (V. B.) egyetemi adjunktus, Zakariás Andrea Beáta (Z. A. B.) joghallgató, Zsiros Bettina (Zs. B.) joghallgató.

\section{AGRÁRJOG, KÖRNYEZETJOG, SZÖVETKEZETI JOG}

- A környezetvédelmi termékdíj 2016. A gyakorlati szakemberek kézikönyve Bartos Gyula-Borsányi-Bognár Levente-Debreczeni László-Kovács Csaba e-Termékdíj.hu Kft., Budapest, 2016 Kézikönyv. Terjedelem: 216. Bibliográfia: 215-216. ISBN 9789631245516 
- A szerzők termékdíjjal foglalkozó, vezető gyakorlati szakemberek, akik az évek óta hasonló címmel megjelent könyvüket aktualizálták, egészítették ki a 2016-ban hatályos elöírásoknak megfelelően. A könyv kifejezetten termékdíjjal foglalkozó szakembereknek, illetve termékdíj-ügyintéző OKJ-s bizonyítványt adó képzésben részt vevő hallgatóknak íródott. Részletesen bemutatja a termékdíjjal kapcsolatos szabályozást (a termékdíj törvény- és végrehajtási rendeleteinek hatálya; termékdíj-kötelezettség; termékdíjraktár; termékdíj visszaigénylése; adóhatósági ellenőrzés; termékdíjbírság; a szabályozásban érintett hatóságok feladatai). A szerzők a szabályozás ismertetésén túl számos helyen példákkal, kiegészítő információkkal segítik a területen történő eligazodást. A hallgatói felkészülést az egyes fejezetek végén található „Ismétlő kérdések” segítik. A korábbi kiadás annotációja a folyóirat 2016/1. számában olvasható. (B. O.)

- Takarékszövetkezetek jogi szabályozása a XIX. és a XX. században Csák Csilla

Novotni Alapítvány a Magánjog Fejlesztéséért, Miskolc, 2016

Monográfia. Terjedelem: 291. Bibliográfia: 280-291. és a lábjegyzetekben. ISBN 9786155658020

- A szerző a Miskolci Egyetem jogi karának oktatója, akinek egyik kiemelt kutatási témája a szövetkezeti jog. Számos tanulmányt közölt korábban a szövetkezeteknek a pénzügyi szektorban betöltött szerepéröl, illetve doktori értekezését is erröl (az integrált takarékszövetkezetekről) írta és védte meg 2000-ben. Jelen kötet elsősorban a disszertáció, illetve a korábbi kutatások eredményeinek egybefoglalása, amely célja s címe szerint a 19. és 20 . század fejleményeivel foglalkozik. Ezen túllépve azonban a szükséges mértékben (pl. a hitelintézeti integráció kapcsán) rámutat a 21. századi jogalkotási termékekre is. Az elemzés kiterjed a szövetkezeti mozgalom, illetve szabályozás hazai, nemzetközi és európai uniós megközelítésére, a takarékszövetkezetek müködési elveire, modelljeire. Mindezek ma és a jövőben is érvényes értékeket hordoznak, amelyek kutatása - mint a szerző bevezetője megfogalmazza - hozzásegíthet ahhoz, hogy maga a szövetkezeti mozgalom túlélhesse a gazdasági versenyt, a válságokat, mégpedig anélkül, hogy a szövetkezeti jelleg sérülne. (F. L.)

- Fenntartható fejlődés: fenntartható termelés és fogyasztás az Európai Unióban HORVÁTH Zsuzsanna

(Sorozat: Institutiones Juris, ISSN 1218-9375; Dialóg Campus Szakkönyvek, ISSN 1417-7986)

Dóm-Dialóg Campus, Budapest-Pécs, 2016

Monográfia. Terjedelem: 216. Bibliográfia: 201-216. és a lábjegyzetekben. ISBN 9879638988966

- A szerző a pécsi jogi kar egyetemi docenseként számos, az EU környezeti politikájával foglalkozó művet jegyez. Korábbi munkáihoz híven a fenntartható fejlődés környezeti dimenzióit mutatja be első helyen, s ahhoz kapcsolja a gazdasági, illetve társadalmi vonatkozásokat. Az EU integrált termékpolitikáját s azzal öszszetartozó hulladékstratégiáját állítja középpontba szakpolitikai, jogi dokumentu- 
mok szisztematikus elemzése révén, miközben meggyőződéssel kárhoztatja a fenntarthatatlan termelési és fogyasztási mintákat. Vállalt $-s$ a könyvben maradéktalanul teljesített - célkitúzése szerint bevezetést, alapokat nyújt a további tanulmányozáshoz, amelyek révén jobban megérthetők a részletszabályok, további szakterületek (mint az energia- vagy agrárpolitika) „zöldülése”, és a szabályozórendszer elemei közötti dinamikus kapcsolatok. A könyv nemcsak a környezetpolitikával foglalkozó jogászok számára, hanem mindenkinek ajánlott olvasmány, aki a világ problémái, jövője, a nemzetközi, illetve az európai uniós politikai fejlemények iránt érdeklődik. (F. L.)

- A genetikailag módositott szervezetekre vonatkozó jogi szabályozásról TAHYNÉ KovÁcs Ágnes

HVG-Orac, Budapest, 2016

Monográfia. Terjedelem: 315. Bibliográfia: 306-315. és a lábjegyzetekben. ISBN 9879632582993

- A szerző 2013-ban a Pázmány Péter Katolikus Egyetemen, annak munkatársaként védte meg „A genetikailag módosított szervezetekre vonatkozó szabályozásról egyes környezetjogi alapelvek, különösen a fenntartható fejlödés tükrében" címü PhD-doktori értekezését. A könyv a disszertáció átdolgozásával jött létre; az eredeti müből a szerző elhagyta a témakör jogrendszerbeli elhelyezésével kapcsolatos, általános elemzést, ugyanakkor bővítette, aktualizálta azt az uniós szabályozás 2015-ben bekövetkezett reformjára tekintettel. A szerző nagymértékben támaszkodott a zöld géntechnológia természettudományos szakirodalmára, $s$ a normatív megközelítést tágan értelmezve a valláserkölcsi vonatkozásoknak is szentelt egy fejezetet. A nemzeti és az európai uniós szabályozás fejlődési útját, rendszerét, elemeit alaposan elemző, de a nemzetközi jogra is kitekintő munka hiánypótló; a technológiai újítások és a GM-növények számának ugrásszerü növekedése miatt napjainkban felforrósodó tudományos és jogalkalmazási vitákban biztos támpontokat ad az előzmények megértéséhez. (F. L.)

\section{ALKOTMÁNYJOG}

- Számadás az Alaptörvényröl: tanulmányok a Szegedi Tudományegyetem Államés Jogtudományi Kar oktatóinak tollából

Balogh Elemér (szerk.)

Magyar Közlöny Lap- és Könyvkiadó, Budapest, 2016

Tanulmánykötet. Terjedelem: 672. Bibliográfia: 623-671. és a lábjegyzetekben. ISBN 9786155269820

- A kötet a Szegedi Tudományegyetem Állam- és Jogtudományi Kara oktatóinak mintegy félszáz tanulmányát adja közre, amelyek csaknem mind kapcsolódnak Magyarország 2011-ben elfogadott Alaptörvényéhez. Első részük az alaptörvényi rendelkezések szakjogági ( $p l$. munkajogi, kereskedelmi jogi, agrárjogi) és alapjogvédelmi aspektusaival (pl. gyermeki jogok) foglalkozik. Ezt követően alkotmányelméletről és az alkotmánybíráskodásról olvashatunk (ideértve az Alaptörvény 
legitimitásának és keletkezésének kérdéseit is), majd az uniós és nemzetközi jogi vonatkozások (mint az Európa-klauzula nemzeti alkotmánybíróságok általi megítélése, a nemzetközi jog lenyomata) következnek. A büntetőjog és a közhatalom alaptörvényi vonatkozásaival (a ne bis idem elvével, a jogos védelemmel vagy az önkormányzatisággal) foglalkozó, majd végül alkotmánytörténeti munkák következnek (pl. a menedékjog gyökereiröl és a szabadságjogok megjelenéséröl). A kötethez Trócsányi László igazságügyi miniszter, egyetemi tanár írt előszót. (B. J. D.)

- Élni és halni hagyni: beszélgetések a holland eutanáziagyakorlatról

BÉRCZEs Tibor

Corvina, Budapest, 2016

Interjúkötet. Terjedelem: 291. Bibliográfia nincs. ISBN 9789631363661

- A szerző író, müfordító. A kötet azt igyekszik bemutatni, hogy a Hollandiában évek óta legális eutanázia lehetőségével milyen feltételek mellett lehet élni, valamint hogy a legalizálás óta eltelt tizenöt év milyen kérdésekkel és dilemmákkal szembesítette a holland társadalmat, és ezekre milyen megoldási javaslatok születtek. Az interjúkötet különböző világnézetet valló személyeket szólaltat meg. Így például James Kennedy történészt, Theo Bohr protestáns erkölcsfilozófust az eutanázia lehetséges határairól, valamint Hans Van Dammot az eutanázia önrendelkezési joggá tételének lehetőségéröl. Olvashatunk továbbá interjút a gyermekeutanázia lehetőségeiről és a pszichiátriai betegek eutanáziához való jogáról is. A kötet nem titkolt célja, hogy a Hollandiában mintegy ötven éve folyó eutanáziavitába adott bepillantással hozzájáruljon az ezzel kapcsolatos magyarországi viták megindulásához. (D. I.)

- Közjog és jogállam: tanulmányok Kiss László professzor 65. születésnapjára Csefkó Ferenc (szerk.)

PTE ÁJK, Pécs, 2016

Tanulmánykötet. Terjedelem: 301. Bibliográfia a lábjegyzetekben. ISBN 9789636429928

- A Pécsi Tudományegyetem Állam- és Jogtudományi Kara 2016. február 19-én köszöntötte Kiss László professzort, volt alkotmánybírót 65. születésnapján. Az alkalomra a Kar Közigazgatási Jogi Tanszékének kezdeményezésére állt öszsze a 25 tanulmányt tartalmazó kötet. A szerzők közül néhányan vallásfilozófiai, politológiai, szociológiai munkákkal köszöntik az ünnepeltet, de a tanulmányok zöme közvetve vagy közvetlenül Kiss László munkásságához, az alkotmány, alkotmányszabályozás, a hatalommegosztás és hatalomgyakorlás, az államszervezet, államigazgatás, önkormányzatok témaköréhez kapcsolódnak. (D. I.)

- Paragrafusokkal a bitek ellen: az internet szabályozásának elmélete és gyakorlata DETREKöI Zsuzsa

(Sorozat: Infokommunikáció és Jog Könyvek, ISSN 2060-5021)

HVG-ORAC, Budapest, 2016

Monográfia. Terjedelem: 173. Bibliográfia: 167-173. és a lábjegyzetekben. ISBN 9789632583037 
- A szerző ügyvéd, médiajogi szakértő. Kötete az ELTE-n 2016-ban megvédett doktori disszertációján alapul. A kötet célja, hogy bemutassa az internet térhódítása révén a jogrendszert érő legnagyobb kihívásokat. Az első rész az internet fogalmának meghatározása után megvilágítja az internet szabályozásával járó problémákat: a károsnak minősített internetes tartalmak illegálissá tétele, illetve tiltása komoly dilemmák elé állítja a jogalkotót, akinek minden esetben mérlegelnie kell a szabályozás lehetséges gazdasági és jogi következményeit. A második rész az internet kontrolljának lehetséges eszközeit mutatja be, azaz az államok internetes tartalmak közzétételét és az ezekhez való hozzáférést megakadályozó technikai, jogi és egyéb eszközeit. A harmadik rész arra a kérdésre keresi a választ, hogy pontosan milyen internetes tartalmakat kell szabályozniuk az államoknak. Ebben a körben szó esik többek között a szexuális, személyiségi jogokat érintő, vallási és politikai tartalmakról, valamint a gyülöletbeszédröl. (R. A.)

- Az Országgyülésről szóló 2012. évi XXXVI. törvényben és az egyes házszabályi rendelkezésekröl szóló 10/2014. (II. 24.) OGY határozatban foglalt házszabályi rendelkezések egységes szerkezetben: 2014-2018-as ciklus

Dukán Ildikó (szerk.)

Bővített kiadás. Országgyülés Hivatala, Budapest, 2016 Jogforrásgyűjtemény. Terjedelem: 288. Bibliográfia nincs. ISBN 9786155674037

- A szerkesztő az Országgyűlés Hivatalának munkatársa. A kötet egységes szerkezetben, tematikusan adja közre az Alaptörvénynek az Országgyüléssel kapcsolatos alapvető rendelkezéseit, az Országgyülésről szóló törvény házszabályi és egyéb rendelkezéseit, továbbá a határozati házszabályi rendelkezéseket. A mellékletek az igen összetett eljárási és egyéb szabályokat áttekintő táblázatokat tartalmaznak. (D. I.)

\section{- A mi alkotmányunk}

EGYEd István

(Sorozat: Államtudományi Klasszikusok, ISSN 2498-7522; 1.)

Az 1943-as kiadás reprintje. Dialóg Campus, Budapest, 2016

Monográfia. Terjedelem: 373. Bibliográfia: 366-373. ISBN 9786155376924

- Egyed István (1886-1966) egyetemi tanár, a közigazgatási és alkotmányjog elismert tudósa volt. Kötetének reprint kiadása a Nemzeti Közszolgálati Egyetem kezdeményezésére jelent meg az Alaptörvény életbelépésének ötéves évfordulóján, az egyetem által a szerző születésének 130. évfordulójára meghirdetett Egyed István Emlékévben. Első megjelenésekor a könyv új feladat betöltésére vállalkozott: a magyar alkotmányt nem annyira tételes rendelkezéseiben, mint szellemében, jelentőségének és jellegzetes vonásainak feltárásával kívánta bemutatni. Célja volt kimutatni, hogy ez az alkotmány több tekintetben különálló történeti fejlődés eredménye, a nemzeti kultúra értékes bizonyítéka, amely különleges helyet foglal el az alkotmányok rendszerében. (D. I.) 
- Jog az egyház hagyományában és életében

ERDŐ Péter

Szent István Társulat, Budapest, 2016

Tanulmánykötet. Terjedelem: 488. Bibliográfia a lábjegyzetekben. ISBN 9789632776354

- A szerző esztergom-budapesti érsek, teológus, kánonjogász és egyetemi tanár. E kötete különféle kánonjogi témákat érintö, magyarul vagy idegen nyelven korábban megjelent tanulmányait gyüjti össze, amelyek egyrészt az egyházjogi hagyomány történeti dimenzióját kívánják bemutatni, másrészt a mai egyházi élet konkrét kérdéseire keresik a jogi válaszokat. A kötet szerkezete az Egyházi Törvénykönyv felosztását követi, ami azzal is jár, hogy a szerző tanulmányait a szükséges mértékben ennek megfelelően átdolgozta. Az írások kitérnek az egyházjog általános fogalmaira, szabályaira, Isten népének jogi szervezettségére, a megszentelés feladatára, az egyház büntetőjogának sajátos fejlődésére és az egyházi eljárásjogban bekövetkezett változásokra. (D. I.)

- Parlamenti autonómia: aktustani elemzések az Országgyülés jogállásáról és hatásköreiröl

ERDös Csaba

(Sorozat: Parlamenti Kötetek, ISSN 2498-5171)

Gondolat, Budapest, 2016

Monográfia. Terjedelem: 350. Bibliográfia: 333-343. ISBN 9789636936457

- A szerző a Nemzeti Közszolgálati Egyetem oktatója. A könyv 2014 februárjában megvédett doktori értekezésének átdolgozott változata, amely arról az évszázados alkotmányjogi dilemmáról szól, hogy vajon a parlament a szuverenitásból eredő összes jogot gyakorolja, autonómiája, hatalma teljes és korlátlan, vagy a parlamentnek, a népszuverenitásnak lehetnek bírái, kontrollmechanizmusai. A kötet a hatalommegosztás elvéből kiindulva tartalmilag, módszertanilag és megközelítési módjában is új perspektívát alkalmaz: aktustani megközelítést alkalmazva tesz kísérletet a parlament döntéseinek és e döntések joghatásainak elemzésére, beleértve az alkotmánymódosítást is. (D. I.)

- Suum cuique: ünnepi tanulmányok Paczolay Péter 60. születésnapja tiszteletére Fejes Zsuzsanna-Török Bernát (szerk.) (Sorozat: A Pólay Elemér Alapítvány Könyvtára, ISSN 1786-352X; 60.) Pólay Elemér Alapítvány-lurisperitus, Szeged, 2016

Tanulmánykötet. Terjedelem: 770 . Bibliográfia az egyes tanulmányok végén és a lábjegyzetekben. ISBN 9786155411342

- A Paczolay Péter professzor, volt alkotmánybíró hatvanadik születésnapjára készült kötet felépítése az ünnepelt pályájához igazodik, ugyanis a negyvenkilenc magyar és angol nyelvű tanulmány szerzői Paczolay Péter egykori és jelenlegi pályatársai az Eötvös Loránd Tudományegyetemen, a Szegedi Tudományegyetemen, az Alkotmánybíróságon és a Köztársasági Elnöki Hivatalban, valamint a Velencei Bizottságban. A szerzők zöme elismert magyar jogtudós, elsősorban a közjogtudomány területéröl, de néhány külföldi pályatárs és társadalomtudo- 
mányi szerző írása is helyet kapott a kötetben. A tanulmányok tematikája igen gazdag; egyaránt olvashatunk az Alaptörvény államfilozófiájáról, a globális javak elosztásáról, az állam jóságának eszmetörténeti változásairól, a jogrendszerek versenyéröl, az életfogytig tartó szabadságvesztésről, az identitás geopolitikai kérdéseiről, a polgári és a polgári eljárásjogi kodifikációról vagy a politika és a jog racionalizálódási folyamatáról. (D. I.)

\section{- Nemzeti alkotmányok az Európai Unióban}

Heka László-Jakó Nóra-Mikes Lili-Pongó Tamás-Szakály Zsuzsa (ford.)

Wolters Kluwer, Budapest, 2016

Kézikönyv. Terjedelem: 997. Bibliográfia az egyes fejezetek elején. ISBN 9789632956039

- A könyv az Európai Unió tagállami alkotmányainak fordításait adja közre. A fordítók a Szegedi Tudományegyetem jogi karának oktatói, kutatói és PhD-hallgatói, akik számos tekintetben aktualizálták a hasonló tartalmú, 2005-ös kötetet. Egyrészt tekintettel voltak az azóta bekövetkezett alkotmánymódosításokra, és a 2015. július 1-jei kéziratlezáráskor hatályos tagállami alkotmányok szövegével dolgoztak (nagyrészt angolul). Másrészt azóta kibővült az Európai Unió, így a munka már Bulgária, Horvátország és Románia alkotmányait is tartalmazza. A kötet a magyar Alaptörvény szövegét a 2016. június 14-i, hatodik módosítással tartalmazza. (F. B.)

- Alkotmányjog: jogi szakvizsga felkészitő kötet

JAKó Nóra-Mikes Lili-SzABó Zsolt

(Sorozat: Jogi Szakvizsga Könyvek)

Második, átdolgozott kiadás. Patrocinium, Budapest, 2016

Tansegédlet. Terjedelem: 256. Bibliográfia nincs. ISBN 9789634131144

- A szerzők egyetemi oktatók. A kötet második, átdolgozott kiadásának anyaga igazodik a jogi szakvizsga Igazságügyi Minisztérium által összeállított hivatalos tételsorához. A tankönyv az egyes témakörökhöz kapcsolódó joganyagot tematikusan, három nagyobb fejezetben tárgyalja, ismerteti a vonatkozó alkotmánybírósági gyakorlatot is, továbbá a jogalkalmazás terén előforduló gyakorlati és jogértelmezési problémákra is reflektál. A tananyag eredményes elsajátítását a vázlatpontokba szedett áttekintés és a félkövér kiemelések segítik. Az első kiadást a Pro Futuro 2017/1. számában annotáltuk. (N. N.)

\section{- Adatvédelmi jog: magyar és európai szabályozás}

JóRI András-Soós Andrea Klára

HVG-ORAC, Budapest, 2016

Kézikönyv. Terjedelem: 372. Bibliográfia a lábjegyzetekben. ISBN 9789632583068

- A szerzők Jóri András ügyvéd, korábbi adatvédelmi biztos és Soós Andrea Klára ügyvéd, uniós jogi szakértő. A könyv az információs jogokról szóló törvény (Infotv.) magyarázata, amely a teljesség igényével dolgozza fel az adatvédelmi gyakorlatot a kilencvenes évektöl napjainkig. Nem követi szorosan az Infotv. szövegét, hanem azon fö jogi kérdések mentén halad, amelyekkel a magyar jogalkalmazó 
szembesülhet. A kötet minden vonatkozó kérdés kapcsán kitér a 2016 májusában kihirdetett, 2018-tól hatályos új uniós adatvédelmi rendeletre (GDPR) és a várható változásokra is. Az alkalmazott terminológia minden esetben már a rendelet hivatalos magyar fordítását tükrözi. (D. I.)

- Alkotmányjogi alapismeretek: Magyarország alkotmányos intézményeinek vázlata Kıss Barnabás

(Sorozat: A Pólay Elemér Alapítvány Tansegédletei, ISSN 1786-3554)

Negyedik, átdolgozott kiadás. Pólay Elemér Alapítvány-lurisperitus, Szeged, 2016 Egyetemi jegyzet. Terjedelem: 179. Bibliográfia nincs. ISBN 9786155411434

- A szerző az SZTE ÁJK oktatója. Az alkotmányjogi jegyzet a korábbi kiadásokhoz hasonlóan a legfontosabb alapfogalmak (mint alkotmány, alkotmányjog, alkotmányosság) definiálásával kezdődik, majd áttekinti Magyarország legfontosabb alkotmányos rendelkezéseit, így a jogalkotás mechanizmusát és a jogforrási rendszert, a választási rendszert, majd a legfőbb alkotmányos intézményeket és a közpénzügyek alkotmányos alapjait. A kötet tartalmazza Magyarország Alaptörvényének teljes szövegét is. Az előző kiadást a Pro Futuro 2016/1. számában annotáltuk. (N. N.)

- Sajtószabadság és médiajog a 21. század elején 3.

Koltay András-Török Bernát (szerk.)

Wolters Kluwer, Budapest, 2016

Tanulmánykötet. Terjedelem: 580. Bibliográfia a lábjegyzetekben.

ISBN 9789632955995

- A szerkesztők egyetemi oktatók, Koltay András a Médiatanács tagja. A mü annak a négykötetes sorozatnak a része, amely az MTA, illetve a Nemzeti Média- és Hírközlési Hatóság együttmüködésében létrejött Médiatudományi Kutatócsoport eredményeit tanulmányok formájában adja közre. A kutatócsoport célja, hogy a szólás- és sajtószabadság aktuális kérdéseit vizsgálja, hozzájárulva ezzel a magyarországi médiajogi vitákhoz. Jelen kötetben a tanulmányok tematikusan, négy nagy szerkezeti egységre tagolva szerepelnek. Az első részben a sajtószabadság jogának alapvető kérdéseivel és alkotmányos vonatkozásaival foglalkozó tanulmányok olvashatók. Ezeket a magánjog és a szólásszabadság kapcsolata témakörében írott elemzések követnek. A harmadik részben az új típusú média egyes szabályozási kérdéseit vizsgáló tanulmányok találhatóak. A kötetet a sajtószabadság egyes speciális kérdéseivel foglalkozó tanulmányok zárják. (B. É.)

- A migráció kockázatai

Kondorosı Ferenc

Alexandra, Pécs, 2016

Monográfia. Terjedelem: 163. Bibliográfia a lábjegyzetekben. ISBN 9789633577448

- A szerző a Budapesti Gazdasági Egyetem professzora. Kötete napjaink egyik legtöbb vitát kiváltó jelenségét, a migrációt kívánja bemutatni, értelmezni, megértéséhez segítséget nyújtani. Az első fejezet a migrációt történelmi, társadalmi kontextusban vizsgálja, a második a biztonsághoz való jog tartalmát, a harmadik 
a vallásszabadság és a gyülöletbeszéd konfliktusát járja körül. A negyedik és az ötödik fejezet az iszlám jogi kultúrát mutatja be. A hatodik fejezet a vitát generáló kérdésekkel foglalkozik, mint pl. a vallási öltözetek jogi megítélése, a minaret- és a mecsetépítések szabályozása vagy a vallásoktatás és a vallási jelképek elhelyezése az iskolákban. A hetedik fejezet a jogot mint a kultúrák és a civilizációk közötti hidat mutatja be. Az összefoglaló az addig leírtak alapján veszi számba az európai és hazai teendőket a migráció jelensége kapcsán. (D. I.)

- A rendszerváltozás államszervezeti kompromisszumai

KUKORELLI István-TótH Károly

(Sorozat: RETÖRKI Könyvek, ISSN 2064-4531; 13.)

Antológia, Lakitelek, 2016

Tanulmánykötet. Terjedelem: 419. Bibliográfia a lábjegyzetekben.

ISBN 9786155428371

- A szerzők alkotmányjogász professzorok, Kukorelli István volt alkotmánybíró. A kötet a Rendszerváltás Történetét Kutató Intézet és Archívum (RETÖRKI) kiadványsorozatában jelent meg, amely szervezetnek a szerzők is külső munkatársai. A hét tanulmányból álló kötet az alkotmányos rendszerváltozás néhány máig vitatott államszervezeti megoldását mutatja be, elsősorban az alkotmányozáshoz és a kormányzati rendszer sajátosságaihoz kapcsolódóan. A szerzők alkotmánytörténeti, alkotmányelméleti és kritikai módszerrel próbálják magyarázni és értékelni az intézményekre ma is jellemző, sok szempontból kuriózumszerủ változásokat. A tárgyalt témakörök érintik többek között az alkotmányozó hatalom, az államfö, az Alkotmánybíróság, a kétkamarás parlament és a kétharmados törvények kérdését. Az egyes tanulmányok idézetekkel, összefoglaló táblázatokkal segítik az olvasót a korszak megismerésében. (B. J. D.)

- Személy és személyiség a jogban

Menyhárd Attila-Gárdos-Orosz Fruzsina (szerk.)

Wolters Kluwer, Budapest, 2016

Tanulmánykötet. Terjedelem: 286. Bibliográfia a lábjegyzetekben.

ISBN 9789632955896

- A kötet az MTA Jogtudományi Intézetének azonos címü kutatási projektje keretében készült. A kutatás annak a kérdésnek a vizsgálatára vállalkozott, hogy hogyan jelenik meg és mit jelent a személyiség védelme a különböző jogterületeken - így az alkotmányjogban, a magánjogban, a büntetőjogban, a médiajogban és az orvosi jogban - Magyarországon, illetve hogy hogyan jelenik meg a személyiségvédelem a jogi szabályozásban és a dogmatikában. A kötetben lévő tanulmányok szerzői azt vizsgálják, hogy az egyes jogterületek milyen emberfelfogásból indulnak ki, és ez alapján a személyiség fogalmának milyen jogi definícióját alkalmazzák. A tanulmányok azt is elemzik, hogy mi lehet az oka az egyes jogterületek közötti eltéréseknek, illetve hogy azok miért szükségesek és hogyan igazolhatók. (B. É.) 
- Alapjogok mérlegen: az általános alapjogi tesztek dogmatikája

PozsÁr-SZENTMIKLÓsy Zoltán

HVG-ORAC, Budapest, 2016

Monográfia. Terjedelem: 267. Bibliográfia: 255-267. és a lábjegyzetekben. ISBN 9789632582948

- A szerző az ELTE Alkotmányjogi Tanszékének oktatója. Kötete az ugyanott 2014-ben megvédett doktori disszertációján alapul. A kötet célja az alapjogi viták feloldására alkalmazott általános teszt módszertani vizsgálata, amely révén sor kerülhet annak szakszerü és következetes alkalmazására. Az alapjogi teszt elemzéséhez szükséges fogalmi keretek megadása után részletesen vizsgálja a szükségességi-arányossági teszt elemzéséhez szükséges, az alapjog-korlátozást igazoló lehetséges jogalkotói célkitűzéseket, illetve az arányossági vizsgálat mibenlétét és gyakorlatát. Külön fejezet foglalkozik az alapjogi teszt további, az általános szempontokon túli elemeivel (lényeges tartalom, mérlegelési jogkör). A kötet az alapjogi tesztek formális és tartalmi rendeltetésének értékelésével és egy rövid összefoglalással zárul. (R. A.)

- Párbeszéd és identitás: az alkotmányos identitás alapkérdései: Budapest 2015. április 23-24.

Sulyok Márton (szerk.)

Magyar Közlöny Lap- és Könyvkiadó, Budapest, 2016

Konferenciakötet. Terjedelem: 167. Bibliográfia nincs. ISBN 9786155269882

- A kötet a 2015 áprilisában Budapesten megrendezett azonos címü konferencián elhangzott előadások írásos változatát tartalmazza. A szerzők között magyar és külföldi jogászokat és politikusokat is találunk. A kötet az alkotmányos identitásról szóló jogi és politikai vitákhoz kíván hozzájárulni. Az előadások központi kérdése, hogy hogyan határozható meg és képviselhető a magyar alkotmányos identitás Európában és a világban, hogyan jelenhet meg ez a fogalom a jogi és politikai diskurzusban, és hogyan válhat érthetővé a közvélemény és a világ számára. (D. I.)

- Dialogue and identity: fundamental questions of constitutional identity: 23-24 April 2015 Budapest = Dialogue et identité: questions fondamentales de l'identité constitutionnelle: le 23-24 avril 2015, Budapest = Dialog und identität: Grundfrage der Verfassungsidentität: am 23-24 April 2015, Budapest

Sulyok Márton (szerk.)

Magyar Közlöny Lap- és Könyvkiadó, Budapest, 2016

Konferenciakötet. Terjedelem: 202. Bibliográfia nincs. ISBN 9786155269882

- Az elöbbi kötet idegen nyelvű kiadása: a címben szereplö konferencián elhangzott előadások szerkesztett változata angol, francia és német nyelven. (D. I.)

- Bevezetés az infokommunikációs jogba

Tóth András-Klein Tamás (szerk.)

(Sorozat: Bethlen-sorozat, ISSN 2062-2546)

Patrocinium, Budapest, 2016

Tankönyv. Terjedelem: 385. Bibliográfia a lábjegyzetekben. ISBN 9789634131304 
- A szerzők egyetemi oktatók. A kötet elsődleges célja, hogy támogassa a Károli Gáspár Református Egyetem jogi karán folyó infokommunikációs jogi bevezető képzést, ám a közreadott anyag több mint egy féléves egyetemi kurzus írásos tananyaga. A tételes szabályok ismertetésén túl az egyes témakörök elméleti elökérdéseit és társadalmi kontextusát is érinti, foglalkozik az infokommunikáció alkotmányjogi, adatvédelmi, szerzői jogi vonatkozásaival, és bemutatja az elektronikus hírközlés, kereskedelem, közigazgatás és aláirás alapvető szabályait. (D. I.)

- Bevezetés az alkotmányjogba: az Alaptörvény és Magyarország alkotmányos intézményei

Trócsányi László-Schanda Balázs (szerk.)

Ötödik, átdolgozott kiadás. HVG-ORAC, Budapest, 2016

Tankönyv. Terjedelem: 513. Bibliográfia az egyes fejezetek végén.

ISBN 9789632583099

- A kötet a Pázmány Péter Katolikus Egyetem, illetve a Szegedi Tudományegyetem jogi karainak együttmüködésében készült, immár az ötödik, átdolgozott kiadásként. A 2012-es első kiadáshoz hasonló szerkezetben, a 2016. augusztus 31-ig bekövetkezett változásokra tekintettel rendszerező áttekintést nyújt az alkotmányos intézményrendszerről. Az Alaptörvény és az ahhoz kapcsolódóan elfogadott új sarkalatos törvények alapján az alkotmányjogi stúdium államszervezeti témaköreit dolgozza fel, kitér továbbá az Alaptörvény keletkezésének körülményeire is. Az előző kiadást a Pro Futuro 2016/2. számában annotáltuk. (D. I.)

\section{BÜNÜGYI TUDOMÁNYOK}

- Ártatlanok vagy bünösök? - Az Egyesült Államok esküdtszékeinek vitatott döntései BADó Attila SZTE ÁJK Összehasonlító Jogi Intézet, Szeged, 2016 Monográfia. Terjedelem: 360. Bibliográfia: 347-360. ISBN 9789633064856

- A szerző egyetemi tanár. Könyvének célja, hogy mind a joghallgatók, mind a szélesebb olvasóközönség számára részletes ismereteket nyújtson az igazságszolgáltatás gyakorlati müködéséről, az esetleges bírói tévedések következményeiről, illetve a média igazságszolgáltatást befolyásoló szerepéről. A monográfia egyik érdekességét az ártatlanul elítélt személyek ismert, illetve kevésbé ismert történetei adják. Az olvasó betekintést nyerhet a korabeli Egyesült Államok igazságszolgáltatási mechanizmusába, az esküdtszék bíráskodásban betöltött szerepébe, a DNS-vizsgálatok hátterében megjelenő szemléletváltás okaiba. A könyv két tárgykört elemez mélyrehatóan. Az egyik az ártatlanul halálra ítélt személyek szabadulási lehetőségeit érinti, a másik pedig az ártatlanság vélelméhez kapcsolódóan az ítéletek helyességét vizsgálja jogelméleti nézőpontból. A könyv végén függelékként azon kérdöívek találhatóak meg, amelyek, az O. J. Simpson-ügyben az esküdtek kiválasztásában játszottak szerepet. (Z. A. B.) 
- Büntetöjog l.: Általános rész

Balogh Ágnes

(Sorozat: Jogi Szakvizsga Segédkönyvek, ISSN 1587-6659)

Hetedik, hatályosított kiadás. Dialóg Campus, Budapest-Pécs, 2016

Tansegédlet. Terjedelem: 280. Bibliográfia: 280. ISBN 9786155376771

- A szerző a Pécsi Tudományegyetem oktatója. E munkája a büntetőjogi szakvizsgára történő felkészülés fontos segédlete. A mủ részletesen dolgozza fel az anyagi büntetőjog általános részének alapvető elméleti tudásanyagát. Ezen túlmenően, figyelemmel a jogi szakvizsga követelményeire, a normaszöveg rendelkezéseit értelmező joggyakorlatot is igyekszik minél szélesebb körben feltárni, ezzel is elősegítve a tananyag hatékonyabb elsajátítását. Az olvasó e munkában ismereteket szerezhet a büntetőjog statikus és dinamikus szegmensét illetően egyaránt. A tankönyv által közvetített tudásanyag összhangban van az Igazságügyi Minisztérium által meghatározott büntető anyagi jogi szakvizsga-követelményekkel. A könyv előző kiadásait a Pro Futuro 2015/2. és 2017/1. számaiban annotáltuk. (B. S.)

- Büntetőjog II.: Különös rész

Balogh Ágnes

(Sorozat: Jogi Szakvizsga Segédkönyvek, ISSN 1587-6659)

Dialóg Campus, Budapest-Pécs, 2016

Tansegédlet. Terjedelem: 595. Bibliográfia: 595. ISBN 9786155680106

- A szerző a Pécsi Tudományegyetem egyetemi docense, gyakorló ügyvéd. A könyv a büntetőjogi szakvizsgára történő felkészüléshez kíván segítséget nyújtani, ezért a büntetőjog dogmatikai alapjaira helyezi a hangsúlyt. Tekintettel mind a kötet, mind a szakvizsga anyagának korlátaira, a szerző mellőzi a történeti és a kriminológiai bevezetőket, és nagyobb figyelmet szentel a gyakorlati jellegű kérdéseknek a jogegységi határozatokon, kollégiumi véleményeken és eseti döntéseken keresztül. A tankönyv az Igazságügyi Minisztérium által közzétett büntető anyagi jogi szakvizsga különös részi tételsorával megegyező sorrendben épül fel, és mind a fejezetek sorszámozása, mind azok címe megegyezik a tételsorban találhatóakkal. Jelen kötet megjelenését az elöző, 2014. évben megjelent kiadás óta eszközölt jogszabály-módosítások indokolták. (J. GY.)

- Büntetőjogi alapismeretek

Bartkó Róbert (szerk.)

Universitas-Győr Nonprofit Kft., Győr, 2016

Egyetemi jegyzet. Terjedelem: 85. Bibliográfia nincs. ISBN 9786155298844

- A szerző a Széchenyi István Egyetem oktatója, jegyzete a jogi asszisztens képzésben segíti a hallgatók felkészülését a büntetőjogi alapismeretek átfogó áttekintésével. Gyakorlati példákkal együtt, önálló fejezetben kerülnek kifejtésre a büntetőjog fogalma és forrásai, alapelvei, a büntetőtörvény rendszere és a törvény hatálya, a büncselekmény fogalma és súly szerinti felosztása, büntethetőségi akadályok rendszere, a bủncselekmény megvalósulási szakaszai, büncselekmény elkövetői, a búncselekményi egységre és a halmazatra vonatkozó szabályok, a magyar szankciórendszer sajátosságai és felépítése, továbbá a büntetések és az intézkedések, valamint azok kiszabása, majd a fiatalkorúakra és a katonákra vonatkozó speciális rendelkezések. (M. E.) 


\section{- Kriminológia}

Borbíró Andrea-Gönczöl Katalin-Kerezsi Klára-Lévay Miklós (szerk.)

Wolters Kluwer, Budapest, 2016

Tankönyv. Terjedelem: 1031. Bibliográfia a fejezetek végén. ISBN 9789632956053

- A szerkesztők az ELTE Állam- és Jogtudományi Kar Kriminológiai Tanszékének oktatói. A kötet huszonhét szerzője pedig a kriminológia elismert hazai szakértöje, felsőoktatási tapasztalattal is rendelkező szakember. A mủ a Kriminológia Szakkriminológia című, utoljára 2012-ben megjelent tankönyv bővített, átdolgozott kiadása, amely négy nagyobb szerkezeti egységre osztva mutatja be a kriminológia legfontosabb vizsgálódási területeit. Az első rész a kriminológiai elméletek nemzetközi és hazai fejlődésével foglalkozik, a második rész a bünözés megismerésének különböző csatornáit ismerteti. A harmadik rész napjaink jellegzetes bűnözési formáit és bünelkövető típusait tárgyalja. Végül a negyedik rész tanulmányai a bünözési kontroll, avagy a kriminálpolitika hazai és nemzetközi alakulásáról adnak áttekintést. A számottevő ismeretanyagot közlő munka szakkönyvként és tudományos ismeretközlő müként is megállja a helyét. (P. T. Á.)

- Az új Btk. és a kapcsolódó jogforrások, bírósági iránymutatások

Czine Ágnes (szerk.)

Második, aktualizált kiadás. HVG-ORAC, Budapest, 2016

Kommentár. Terjedelem: 671. Bibliográfia nincs. ISBN 9789632583020

- A könyv szerkesztője alkotmánybíró, a Károli Gáspár Református Egyetem egyetemi docense. A 2012. évi Büntetö Törvénykönyv kommentárjaként a Btk. normaszövegét tartalmazza, hozzárendelve a törvény indokolását, egyéb jogszabályokat (mint az Alaptörvényt, a Btk. háttérjogszabályait, továbbá az Európai Unió jogának vonatkozó rendelkezéseit), illetve a releváns bírói gyakorlatot is, ezen belül az Alkotmánybíróság, valamint a Kúria jogértelmezését. A kötet a 2014-ben ugyanezen címmel megjelent könyv második, aktualizált kiadása, mely követi az első kiadás megjelenése óta bekövetkezett jogszabályi változásokat, az azóta kiadott elvi határozatokat, iránymutatásokat. Az első kiadást a Pro Futuro 2016/1. számában annotáltuk. (H. D.)

- Tételek, gondolatok a kriminológia tudományából

Dомокоs Andrea-Nemes Zsófia

(Sorozat: Bethlen, ISSN 2062-2546)

Patrocinium, Budapest, 2016

Tanulmánykötet. Terjedelem: 222. Bibliográfia: 209-222. ISBN 9789634130819

- A szerzők a Károli Gáspár Református Egyetem oktatói. E kötet a Kriminológia köréből gondolatébresztő jelleggel villant fel számos elméleti szempontból releváns kérdést. A mú két részre bontható. Az első szerkezeti egység a Kriminológia kurzus előadásának tematikája mentén mutatja be a kriminológia tudományának európai kialakulását, kezdeti dogmatikai iskoláit, kutatásait. Ugyanitt szó esik a magyar kriminológia rövid történetéröl, a deviancia és a bünözés kapcsolatáról, a gyermek- és fiatalkori bünelkövetés gyökereiröl, illetve az állam kriminálpolitikai reakcióiról. A második rész Domokos Andrea reflexióra ösztönző, érdekes tanul- 
mányait tartalmazza a tárgyalt tudomány inter- és multidiszciplináris jellegéről, valamint 21. századi új kihívásairól. E tanulmánykötet figyelemfelkeltő és hasznos olvasmány a kriminológiával hivatásból, kedvtelésből foglalkozók számára, és természetesen a joghallgatók számára is. (B. S.)

- A munkát nem lehet eltitkolni. Tiszteletkötet Tremmel Flórián professor emeritus 75. születésnapjára

Fenyvesi Csaba-Herke Csongor (szerk.)

Pécsi Tudományegyetem Állam- és Jogtudományi Kara, Pécs, 2016

Tanulmánykötet. Terjedelem: 101. Bibliográfia a lábjegyzetekben.

ISBN 9789634290476

- Az itt közölt tanulmányok tizenöt szerzője egyetemi oktató, gyakorló jogász. A tanulmánykötet Tremmel Flórián professor emeritus 75. születésnapja alkalmából készült, amit egy tudományos konferencia is követett 2016. június 21-én, a pécsi jogi kar Büntető és Polgári Eljárásjogi Tanszéke szervezésében. A szerzők röviden ismertetik az ünnepelt munkásságát a kriminalisztika, illetve az oktatás területén, majd saját területükre fókuszálva büntető eljárásjogi, kriminalisztikai, nyelvtörténeti, polgári eljárásjogi témakörökben saját eredményeikkel tisztelegnek az ünnepelt előtt. (M. E.)

- AD VALOREM: Ünnepi tanulmányok Vida Mihály 80. születésnapjára

Gál Andor-Karsai Krisztina (szerk.)

(Sorozat: A Pólay Elemér Alapítvány Könyvtára, ISSN 1786-352X; 61.)

Pólay Elemér Alapítvány, lurisperitus, Szeged, 2016

Tanulmánykötet. Terjedelem: 366. Bibliográfia a lábjegyzetekben.

ISBN 9786155411397

- Az ünnepi kötet címzettje Vida Mihály, a Szegedi Tudományegyetem Állam- és Jogtudományi Karának címzetes egyetemi docense, a szerzők pedig munkatársai, pályatársai. A köszönetnyilvánítást követően harminc tanulmányt olvashatunk, amelyek számos büntetőjogi kérdésről értekeznek, úgymint a rendszeres elkövetés kérdésköre, a büntetőeljárás időszerűsége vagy éppen a sértett érdekei az új büntetőeljárási kódexben. A könyvben bemutatásra kerül továbbá egy igen aktuális téma, a migráció a védő szemszögéből, valamint az új büntetőeljárási törvény rendes jogorvoslati kérdéseivel kapcsolatos elképzelések és elvárások, illetve az üzleti titok és a know-how büntetőjogi védelme is a témák közt szerepel. A kiadványban feldolgozásra kerülnek olyan nemzetközi büntetőjogi témák is, mint például a nemzetközi bűncselekmények szabályozása a horvát büntető törvénykönyvben és annak összehasonlítása a magyar, a bosznia-hercegovinai és a szerb szabályozással, illetve a letartóztatások nemzetközi feltételei is. (J. GY.)

- Magyar büntetőjog: Különös részi ismeretek

Görgényi llona (szerk.)

Miskolci Egyetem, Miskolc, 2016

Tankönyv. Terjedelem: 210. Bibliográfia nincs. ISBN 9786155216671

- A 2014-es kiadás változatlan utánnyomása. (B. S.) 
- Idegen a büntetőjogban

HAUTZINGER Zoltán

AndAnn, Pécs, 2016

Monográfia. Terjedelem: 184. Bibliográfia a fejezetek végén.

ISBN 9789638922410

- A könyv szerzője a Nemzeti Közszolgálati Egyetem oktatója. A monográfia a néhány évvel ezelőtt reflektorfénybe kerülő és hazánkat is nagy mértékben érintő migráció kérdéskörére reagálva vázolja fel a külföldiekkel összefüggő büntetőjogi szabályozás rendszerét, annak anyagi, eljárásjogi és büntetés-végrehajtási, jogi vetületét egyaránt. A szerző nem csupán áttekintést kíván adni, hanem a tárgyalt normastruktúra hatásait is vizsgálja a népvándorlás jelenségére nézve. Érdekfeszítő kérdésfelvetéseivel s azok teljesség igénye nélküli megválaszolásával a mú érdekes és mérvadó olvasmány azok számára, akik behatóbb ismeretekre kívánnak szert tenni a migrációval összefüggésben jelentkező büntetőjogi problémákról. (B. S.)

- Az osztrák és a spanyol büntetőeljárás alapintézményei

HeRKE Csongor

PTE ÁJK, Pécs, 2016

Egyetemi jegyzet. Terjedelem: 158. Bibliográfia: 159-160. ISBN 9789634290957

- A szerző a Pécsi Tudományegyetem Állam- és Jogtudományi Karának oktatója, ügyvéd. A jegyzet elsődleges célja nem a spanyol és az osztrák büntetőeljárás összehasonlító jog eszközeivel történő összevetése, hanem a két állam főbb büntető eljárásjogi intézményeinek párhuzamos bemutatása. Különös hangsúlyt fektet a kényszerintézkedésekre (azon belül a titkos eszközökre), a sértetti vádképviseletre és a különeljárások bemutatására. A vizsgálat tárgyát képezte a vádalku spanyol rendszere, a fokozatosság a kényszerintézkedések elrendelésében, a közbenső eljárás koncentrációja vagy a laikus bíráskodás rendszere. A könyv keletkezése egybeesett az új büntetőeljárási törvény kodifikációjával, s a szerző néhány megfigyelése a szükséges adaptációs munkák elvégzését követően megjelent az új törvényben is. (Zs. B.)

- Decemanni in Europaea Unione V.: Tanulmányok a bünügyi tudományok köréböl Róth Erika (szerk.)

(Sorozat: Miskolci Jogtudományi Múhely, ISSN 1589-1518; 10.)

Miskolci Egyetem, Miskolc, 2016

Tanulmánykötet. Terjedelem: 174. Bibliográfia a lábjegyzetekben. ISBN 9786155626081

- A szerzők a Miskolci Egyetem Állam- és Jogtudományi Karának oktatói. A kötet a 2014-ben Miskolcon megrendezett Bünügyi Oktatók Találkozóján elhangzott elöadások írott változatai. A tanulmányok olyan bünügyi tudományokkal kapcsolatos témákat tartalmaznak, amelyek az Európai Unió jogalkotási tevékenységi körébe tartoznak. A könyvben olvashatunk a helyreállító igazságszolgáltatás európai jövőképéről, valamint ehhez a témához szorosan kapcsolódó uniós modellprojekt aktuális eredményeiről is, továbbá a konfliktuskezelés és mediáció egyes kérdé- 
seiről. A tanulmánykötet ismerteti a tájékoztatáshoz való jogot, bemutatja a jogi személyiségű vádlottak büntetőjogi felelősségét, áttekinti a büntetés-végrehajtási szakban alkalmazható közösségi szankciókat. Végül a szerzők az adócsalás és pénzhamisítás elleni uniós törekvésekkel és fellépési lehetőségekkel foglalkoznak. (J. GY.)

- Büntetőjog a Han-kori Kínában

SALÁt Gergely

(Sorozat: PANTA Pázmány Nemzetközi Tanulmányok, ISSN 2416-1438; 4.)

Typotex, Budapest, 2016

Monográfia. Terjedelem: 296. Bibliográfia: 289-296. ISBN 9789632798608

- A szerző a Pázmány Péter Katolikus Egyetem Bölcsészet- és Társadalomtudományi Karának oktatója. A könyv a Kr. e. 206-Kr. u. 220 között fennálló Handinasztia vezette Kínát mutatja be, mely korszak jelentősége az ország életének valamennyi területén, így a jogrendszer tekintetében is meghatározó volt, s hatása mind a mai napig érezhető. A könyv a bevezetés után szerkezetileg tizenkét fejezetre tagolódik. Ismerteti a korszak történeti hátterét és a korabeli jogforrásokat, azok létrejöttének történeti folyamatait. Ezt követően a büntetőeljárások menetét és annak résztvevőit ismerhetjük meg. Majd egy mai értelemben vett büntető anyagi jogi rész következik, hiszen a szerző ismerteti, hogy mely cselekmények minősültek bűncselekménynek, illetve milyen tényezőket, körülményeket mérlegeltek a bírók az ítélethozatal során. Ezt követően áttekintést kapunk arról is, hogy milyen büntetéseket ismert az ókori kínai igazságszolgáltatás. A könyv tartalmazza továbbá a feldolgozott kínai jogi dokumentumok magyar fordítását is. (H. D.)

\section{EURÓPA-JOG ÉS NEMZETKÖZI JOG}

\section{- A magyar külügyi igazgatás alapjai}

BÁBA Iván-BALLER Barbara-HALÁsz Iván-TótH Norbert

Dialóg Campus, Budapest, 2016

Tankönyv. Terjedelem: 214. Bibliográfia a lábjegyzetekben. ISBN 9786155680113

- A szerzők a Nemzeti Közszolgálati Egyetem, valamint a Corvinus Egyetem oktatói. A kötet célja, hogy a külügyi igazgatás rendszerét történeti előzményeivel együtt minél teljesebben, de közérthető módon mutassa be. A történeti háttér és az egyes igazgatási modellek bemutatása, illetve a hatályos szabályozás általános áttekintése után külön fejezet foglalkozik a konzuli igazgatással (a konzuli tisztviselő érdekvédelmi feladatai mellett kitérve az útlevélrendészet és a vízumrendészet, valamint a közigazgatási hatósági feladatok körére), a diplomáciai kapcsolatok alapjaival és az önkormányzatok külkapcsolataival. A tankönyv kitér az Európai Unió külkapcsolatainak tárgyalására, illetve a nemzetközi jogi alapokra (szerződések kötése, nemzetközi szervezetek müködése) is. A kötet elektronikusan teljes terjedelmében elérhető az NKE honlapján. (B. A.) 
- European Banking Union: Congress Proceedings Vol. 1.

Bándi Gyula-Darák Péter-Halustyik Anna-Láncos Petra Lea (szerk.)

Wolters Kluwer, Budapest, 2016

Konferenciakötet. Terjedelem: 622. Bibliográfia a lábjegyzetekben. ISBN 9789632955650

- A kötet az Európai Jog Nemzetközi Szövetsége (FIDE) XXVII. Kongresszusán, Budapesten 2016 májusában bemutatott kutatások eredményeinek szerkesztett változatát tartalmazó, négy kötetből álló kiadványsorozat első darabja. Az angol, német és francia nyelvű írások a tagállamok álláspontjait mutatják be az európai bankunió témakörében. A 18 tagállam helyzetéröl közreadott jelentések alapja egy egységes, 42 kérdésből álló kérdőív volt. A kérdések három nagy témakörhöz kapcsolódnak: az egységes felügyeleti mechanizmushoz, az egységes szanálási mechanizmushoz és az egységes bankszabályozási szabálykönyvhöz. Az egyes nemzeti jelentések legfontosabb konklúzióit összefoglaló általános jelentés külön fejezetben kapott helyet. A munka e-könyv formában ingyenesen letölthető a konferencia honlapjáról. (Sz. D.)

- Private Enforcement and Collective Redress in European Competition Law: Congress Proceedings Vol. 2.

Bándi Gyula-Darák Péter-Láncos Petra Lea-Tóth Tihamér (szerk.)

Wolters Kluwer, Budapest, 2016

Konferenciakötet. Terjedelem: 830. Bibliográfia a lábjegyzetekben. ISBN 9789632955674

- A kötet az Európai Jog Nemzetközi Szövetsége (FIDE) XXVII. Kongresszusán, Budapesten 2016 májusában bemutatott kutatások eredményeinek szerkesztett változatát tartalmazó, négy kötetből álló kiadványsorozat második darabja. Az angol, német és francia nyelvü kötet a magánfelek általi jogérvényesítés és a kollektív jogorvoslat kérdéseivel foglalkozik az európai versenyjog viszonylatában. 23 tagállami jelentést tartalmaz az európai uniós versenyjogi szabályozás érvényesüléséről, amelyek egy 66 kérdésből álló, egységes kérdőív alapján készültek. Külön fejezetben szerepel az Európai Bizottság álláspontját bemutató intézményi jelentés, valamint az egyes nemzeti jelentések lényeges megállapításait összefoglaló általános jelentés. A munka e-könyv formában ingyenesen letölthető a konferencia honlapjáról. (Sz. D.)

- Division of Competences and Regulatory Powers between the EU and the Member States: Congress Proceedings Vol. 3.

Czuczai Jenő-Darák Péter-Láncos Petra Lea-Szabó Marcel-Varga Zs. András (szerk.)

Wolters Kluwer, Budapest, 2016

Konferenciakötet. Terjedelem: 756. Bibliográfia a lábjegyzetekben.

ISBN 9789632955698

- A kötet az Európai Jog Nemzetközi Szövetsége (FIDE) XXVII. Kongresszusán, Budapesten 2016 májusában bemutatott kutatások eredményeinek szerkesztett változatát tartalmazó, négy kötetből álló kiadványsorozat harmadik darabja. $\mathrm{Az}$ 
angol, német és francia nyelvű kötet az Európai Unió és a tagállamok közötti hatáskörmegosztás témakörével foglalkozik. A sorozat első két kötetéhez hasonlóan e kiadvány is tartalmaz egy 27 kérdésből álló, a tagállamoknak előzetesen megküldött egységes kérdőívet, amelynek célja felmérni a tagállamok jogalkotása, bírói fórumai és jogirodalma álláspontját az uniós hatáskörmegosztással kapcsolatban. A kérdöívre válaszként beérkezett 20 tagállami jelentés mellett e kötet is önálló fejezetet szentel a nemzeti jelentések megállapításait összegző általános jelentésnek. A munka e-könyv formában ingyenesen letölthető a konferencia honlapjáról. (Sz. D.)

- Speeches and Presentations from the XXVII FIDE Congress: Congress Proceedings Vol. 4.

Bándi Gyula-Darák Péter-Debisso Kinga (szerk.)

Wolters Kluwer, Budapest, 2016

Konferenciakötet. Terjedelem: 212. Bibliográfia a lábjegyzetekben.

ISBN 9789632955933

- A kötet az Európai Jog Nemzetközi Szövetsége (FIDE) XXVII. Kongresszusán, Budapesten 2016 májusában bemutatott kutatások eredményeinek szerkesztett változatát tartalmazó, négy kötetböl álló kiadványsorozat negyedik darabja. Ebben az utolsó kötetben a konferencián elhangzott - angol, francia és német nyelvű - plenáris előadások szerkesztett változatai kaptak helyet. Az európai jogtudomány neves képviselői által tartott előadások számos, az Európai Unió és az uniós jog jelene és jövője szempontjából meghatározó kérdést érintenek, például a transzatlanti szabadkereskedelmi megállapodás (TTIP) várható hatásait, az európai bankunió fejlődési irányait vagy az Európai Unió nemzetközi kapcsolatokban betöltött szerepét. A munka e-könyv formában ingyenesen letölthető a konferencia honlapjáról. (Sz. D.)

- A kisebbségek jövője a globalizálódó világban

Gömbös Ervin (szerk.)

Magyar ENSZ Társaság, Budapest, 2016

Konferencia kiadvány. Terjedelem: 96. Bibliográfia: 92-96. és a lábjegyzetekben. ISBN 9789638972811

- A kötet a Magyar ENSZ Társaság által 2015 decemberében és 2016 februárjában szervezett konferenciák utókötete. A Magyarországot érintő témákra fókuszáló előadások a kisebbségvédelem átfogó nemzetközi jogi szabályozását, a fogalom meghatározásának nehézségeit, a kisebbségi jogi normaalkotással kapcsolatos problémákat, illetve a védelmi felelösség elvének érvényesülését is elemzik. A kötet igyekszik átfogó képet adni egyrészt a külhoni magyarok aktuális helyzetéröl és Magyarország kapcsolódó kormányzati politikájáról, másrészt az ENSZ keretein belül működő kisebbségvédelmi mechanizmusokról is. (B. A.)

- Nemzetközi közjog

Kovács Péter

(Sorozat: Osiris tankönyvek, ISSN 1218-9855) 
Harmadik, átdolgozott, bővített kiadás. Osiris, Budapest, 2016

Tankönyv. Terjedelem: 795. Bibliográfia: 786-790. és a fejezetek végén. ISBN 9789632753

- A szerző egyetemi tanár, 2005-2014 között az Alkotmánybíróság, 2015 óta a hágai Nemzetközi Büntetőbíróság bírája. A tankönyv harmadik, bővített és aktualizált kiadása a korábbiakhoz hasonlóan gyakorlati megközelítéssel tárgyalja a nemzetközi közjog ismeretanyagát. Részletesen, számos gyakorlati példán keresztül mutatja be az egyes nemzetközi ítélkező fórumok gyakorlatát, különös hangsúlyt fektetve a Nemzetközi Bíróság joggyakorlatára. A nemzetközi jog forrásain túl kitér a magyar jogrendszer releváns változásaira, az Alaptörvény elfogadását követően született alkotmánybírósági határozatokra. Az emberi jogok nemzetközi védelmével is foglalkozik, kitérve az ENSZ által foganatosított reformok elemzésére, így az erőszak alkalmazásával összefüggő humanitárius intervenció vizsgálatára. A gyakorlati megközelítés jelenik meg a diplomáciai és konzuli jog, illetve az államfelelősség és az egyén büntetőjogi felelössége tárgyalásakor is. $A z$ előző kiadást a Pro Futuro 2013/1. számában annotáltuk. (B. A.)

- Az Európai Unió gazdasági joga globális kontextusban

NAGY Csongor István

HVG-ORAC, Budapest, 2016

Monográfia. Terjedelem: 229. Bibliográfia a lábjegyzetekben. ISBN 9789632583105

- A szerző egyetemi tanár, ügyvéd, választottbíró, az MTA-SZTE Lendület „Föderális piacok" kutatócsoport vezetője. Újszerü gondolatkísérletként, összehasonlító jogi kitekintéssel mutatja be az Európai Unió gazdasági jogát: a szabad mozgás jogát és az uniós versenyjogot és versenypolitikát. Párhuzamba állítja az uniós szabályozást a világ más kereskedelmi (WTO) és föderális (amerikai, ausztrál) rendszereinek megoldásaival, gyakorlatával. Ebben a keretben tárgyalja és értékeli az uniós versenyjog céljait, az antitrösztjog hatályát, a vállalkozásokra vonatkozó versenyszabályokat, a liberalizációs versenyjogot és az állami támogatásokat. (N. E. É.)

- Egységes jog, egységes értelmezés? Az uniós jog értelmezése a tagállami bíróságok szintjén

Somssich Réka

(Sorozat: ELTE Jogi Kari Tudomány, ISSN 2060-9361; 37.)

ELTE Eötvös, Budapest, 2016

Monográfia. Terjedelem: 286. Bibliográfia: 267-280. és a lábjegyzetekben. ISBN 9789633122662

- A szerző az ELTE ÁJK oktatója. Monográfiájában az Európai Unió jogának tagállami bíróságok általi értelmezését vizsgálja. Központi kérdése, hogy milyen kapcsolat mutatható ki az önálló tagállami jogértelmezés és az uniós jog egységes érvényesülése között - különös figyelemmel mindazon tényezőkre, amelyek eredményeként a nemzeti bíróságok jogértelmezésük során mellőzik az uniós alapszerződések biztosította együttmüködési lehetőséget az Európai Unió Bíróságával. A szerző az egységes érvényesülés kapcsán részletesen foglalkozik 
azzal is, hogy mennyiben válhatnak nemzetközileg elfogadott precedensekké a tagállami bíróságok önálló jogértelmezései, és kitér e jogértelmezések tagállami felsőbíróság vagy az Európai Bíróság általi felülírásának lehetőségeire és e revíziók lehetséges következményeire is. (Sz. D.)

- A Bécsi Vételi Egyezmény, mint nemzetközi lingua franca - Az egységes értelmezés és alkalmazás újabb irányai és eredményei

SzABó Sarolta

(Sorozat: A Pázmány Péter Katolikus Egyetem Jog- és Államtudományi Karának Könyvei. Doktori értekezések, ISSN 2064-1907; 3.)

Pázmány Press, Budapest, 2016

Monográfia. Terjedelem: 340. Bibliográfia: 287-309. és a lábjegyzetekben. ISBN 9789633081723

- A 2014-es kiadás változatlan utánnyomása. Annotációját lásd a Pro Futuro 2016/2. számában. (Sz. M.)

- Az Európai Unió joga

VÁRnAY Ernő-PAPP Mónika

Negyedik, átdolgozott kiadás. Wolters Kluwer, Budapest, 2016

Tankönyv/Kézikönyv. Terjedelem: 1162. Bibliográfia: 1133-1162. és a lábjegyzetekben. ISBN 9789632955254

- A szerzők az Európai Unió jogának elismert kutatói, egyetemi oktatók. Az immár negyedik kiadásban megjelent, átdolgozott kiadás továbbra is alapmünek számít az uniós joggal foglalkozó joghallgatók és gyakorló jogászok számára. A nagyobb szerkezeti egységek a korábbi kötetek tematikáját követik: az európai integrációs szervezet fejlődése, intézményrendszer, uniós jogi alapelvek, belső piac, versenyjog. A szerzők célja a 2013-as harmadik kiadás tartalmának bővítése volt az azóta bekövetkezett lényeges uniós és magyar jogi fejlemények tekintetében. A köteten belüli keresés megkönnyítésére megújult jogesetmutató szolgál. A kötet a MeRSZ szolgáltatás keretében digitális formában ingyenesen is elérhető. Korábbi kiadását a Pro Futuro 2011/1. számában annotáltuk. (F. B.)

\section{JOGBÖLCSELET}

- "Nincs füst, ahol nincsen tüz” - Az ártatlanság vélelmének érvényesülése a magyar büntetőbíróságok gyakorlatában

Bencze Mátyás

Gondolat, Budapest, 2016

Monográfia. Terjedelem: 194. Bibliográfia a lábjegyzetekben. ISBN 9789636936747

- A szerző a Debreceni Egyetem Állam- és Jogtudományi Karának egyetemi professzora, az MTA tudományos munkatársa. Könyvében az ártatlanság vélelmének, így a bünösség kimondásához szükséges bizonyosság szintjének hazai bírói gyakorlatban megjelenő mértékét, közelebbről meghatározva az in dubio pro reo szabály alkalmazását vizsgálja, empirikus kutatások eredményeire támaszkodva. 
A mủ érdeme, hogy rámutat a bírói gyakorlat által követett mintákra, szokásokra, mintegy tükröt tartva a jogalkalmazás számára. A szerző nemcsak elemzést ad az általa tapasztalt jelenségekről, de tapasztalataihoz elméleti háttérrel megalapozott magyarázatokat is füz. A mű utolsó fejezetében a bírák kiválasztására és képzésére, valamint tevékenységük jogi hátterére vonatkozóan is változtatási javaslatokkal él. (G. A.)

\section{- A jogfilozófia alapvető kérdései és elemei}

FRIVALDSZKY János

Szent István Társulat, Budapest, 2016

Harmadik, javított és bővített kiadás.

Tankönyv. Terjedelem: 360. Bibliográfia a fejezetek végén. ISBN 9789632776620

- A szerző jogfilozófus, politológus, tanszékvezető egyetemi tanár. Célja, hogy egységes koncepcióban, fejezetekre osztva mutassa be a jogfilozófia által ismert fogalmakat, jogintézményeket, emlékeztetve a modern jogelmélet képviselőit a hagyományos jogi gondolkodásra. Bemutatja, hogy a klasszikus kor jogászai számára mit jelentett a jog, a jogi érvelés, szembeállítva napjaink jogfogalmával. Kimerítően foglalkozik a büntetés elméleti igazolásával, az emberi jogok, valamint a házasság és család jogfilozófiai alapjával, a természetjog és a jogszociológia kapcsolatával. Mindemellett kritikai elemzést ad a jogpozitivizmus föbb képviselőinek, így Jhering, Kelsen és Hart elméleteiröl. A könyv végezetül értékelő megközelítésben tárgyalja a felek jogválasztása nyomán a jogalanyok döntéseiért versengő jogrendszereket, amelyek napjainkra jó vagy rossz „minőségü”, lecserélhető „termékekké" váltak. Korábbi kiadását a 2015/1. számban annotáltuk. (G. A.)

\section{- Orbis luris. Ünnepi tanulmánykötet Szabó Miklós 65. születésnapjára}

Hegyi Szabolcs-Vinnai Edina-Ződi Zsolt (szerk.)

Bíbor Kiadó, Miskolc, 2016

Tanulmánykötet. Terjedelem: 198. Bibliográfia a lábjegyzetekben. ISBN 9786155536373

- A kötet szerzői jogfilozófusok, egyetemi oktatók. Ez a munka Szabó Miklós jogász professzor 65. születésnapjára készült, aki a hazai jogelméleti gondolkodás meghatározó alakja. A kötet célja, hogy az általa kifejtett jogelméleti gondolatokra - kritikai perspektívából - reagáljanak azok, akikre elméleti megfontolásai hatással voltak. Így a kötet szerzői három olyan témakörben reagálnak Szabó Miklós munkásságára, amelyekben maradandót alkotott. A dogmatika témakörén belül olvashatunk a jogdogmatika és a bírói érvelés kapcsolatáról, vagy a dogmatika politikai karakteréröl, a logika/retorika tárgyterületén belül a méltányosság és a joghézag vagy a normák igazságértékének kérdése kerül terítékre. A jog és nyelv témájában a jog nyelvi meghatározottságának problémáit vizsgálják a szerzők. (F. K.)

- Törvényszéki retorika, jogászi érvelés

Könczöl Miklós (szerk.)

(Sorozat: A Pázmány Péter Katolikus Egyetem Jog- és Államtudományi Karának Könyvei. Tanulmányok, ISSN 2061-7240; 33.) 
Pázmány Press, Budapest, 2016

Tanulmánykötet. Terjedelem: 143. Bibliográfia a lábjegyzetekben.

ISBN 9789633082676

- A kötet szerzői az ókortörténet, jogelmélet, valamint jogtörténet területén kutatásokat végző egyetemi oktatók. A jogtudomány részéről fontosak azok a törekvések, amelyek feltárják a jog természetével, jogászi érveléssel és jogi gyakorlattal kapcsolatos kérdéseket, amelyek már az ókor óta foglalkoztatták a jog és politikai filozófia múvelőit. $E$ kötet célja, hogy a jogi érvelés sajátosságait tárgyalja ókori szerzők (például Cicero, Ulpianus) munkáinak elemzésén keresztül. A kötet kilenc tanulmányból áll, a tanulmányok által felvetett kérdések a jogászi érvelés karakterét érintik, mint például azt, hogy mit tekinthetünk valódi jogászi érvnek a törvényszéki beszédben, milyen kapcsolódási pontok fedezhetők fel a jog elmélete és gyakorlata között, vagy hogy milyen erkölcsi dilemmák merülhetnek fel az ítélkezés során. Kétségtelen, hogy ezek a kérdések a jogtudomány örök, a mai napig megválaszolatlan problémái, az ezekkel kapcsolatos tudományos vitákból, a problémákra adott válaszokból a 21. század jogásza is hasznos tudásra tehet szert. (F. K.)

\section{- A jogtudományok kutatási módszerei (Kutatásmódszertan)}

Szalma József

Patrocinium, Budapest, 2016

Monográfia. Terjedelem: 255. Bibliográfia a lábjegyzetekben.

ISBN 9789634131106

- A szerző egyetemi tanár, a Vajdasági Magyar Tudományos Társaság alapító tagja és elnöke. Tudományos munkáiban a polgári, a kisebbségi és az emberi jogok témakörét dolgozza fel. E könyv azonban a Károli Gáspár Református Egyetem jogi doktori iskolájában tartott előadásainak szerkesztett változata, amelyben bemutatja a főbb módszertani és jogértelmezési elméleteket, ezzel támpontot adva a jogalkotás és jogalkalmazás gyakorló jogászai számára is. A jogtudományi kutatások kutatástechnikai kérdéseivel, a tudományos (doktori) képzési rendszerrel, valamint a hazai és külföldi jogtudományi folyóiratokkal foglalkozó fejezetek rendkívül hasznos iránymutatást adnak a jogi doktori iskolák hallgatói számára. (G. A.)

\section{- Múltunk öröksége. Elmélettörténeti perspektívák}

SzaBAdFALVI József

Gondolat Kiadó, Budapest, 2016

Tanulmánykötet. Terjedelem: 197. Bibliográfia a lábjegyzetekben. ISBN 9789636936587

- A szerző jogbölcsész, a Debreceni Egyetem Állam- és Jogtudományi Karán egyetemi tanár. Művének jelentősége abban áll, hogy olyan témaköröket érint, amelyeket a magyar jogelméleti irodalomban nem vagy érintőlegesen tárgyalnak. A szerző célja ugyanis, hogy felhívja a figyelmet arra a belátásra, amely szerint a jogtudomány múltban elért eredményeinek ismerete nélkül a jelen kor jogi problémáit nehezen tudnánk megérteni és kezelni. Ezért könyvében 12 fejezetben tárgyalja azon magyar jogelméleti gondolkodók pályaképét és elméleti munkásságát, akik a 19. 
század első harmadától a 20. század közepéig nagy hatással voltak a magyar jogbölcseleti gondolkodás fejlődésére. A számos eltérő nézőpont és pályakép mögött azonban meghúzódik egy közös sajátosság is: a kötetben tárgyalt munkák azon célja, hogy a magyar jogelméleti hagyomány modernizálásában szerepet játsszanak. A kötetben helyet kapott többek között Virozsil Antal, Pauler Tivadar, Finkey Ferenc, Moór Gyula, Vas Tibor vagy Losonczy István jogelméleti munkássága. (F. K.)

- Állambölcseleti töredék. Somló Bódog írásai és hátrahagyott jegyzetei egy megírni tervezett Állambölcseletböl

Takács Péter (szerk.)

(Sorozat: Florilegium. Series lurisprudentiarum ac Politicarum. ISSN 2416-1500; 2.) Gondolat Kiadó, Budapest, 2016

- Somló Bódog a 20. század első felének legjelentősebb hazai jogfilozófusa volt. 1917-ben írta meg Juristische Grundlehre címú jogbölcseleti munkáját, amelynek köszönhetően nemzetközi elismertségre is szert tett. Két évvel e munka megírása után kezdte kidolgozni állambölcseleti tárgyú múvét, amellyel válaszokat próbált találni korának politikai változásaira. Tragikus halála miatt azonban nem tudta befejezni e művét. A Takács Péter által szerkesztett kötet első része Somló tervezett kötetének kéziratban maradt részleteit tartalmazza, a második részében olvashatjuk Takács Péter és Varga Csaba Somló állambölcseletéröl szóló írásait, valamint Somló életútjába és életpályájába is betekinthetünk a kötet függelékében. (F. K.)

- Jog-és állambölcselet

VISEGRÁdY Antal

Menedzser Praxis, Budapest, 2016

Tankönyv. Terjedelem: 229. Bibliográfia a fejezetek végén. ISBN 9786155554056

- A szerző egyetemi tanár, jogfilozófus. A tankönyv célja az állam- és jogbölcselet korszerü, a magyar- és egyetemes jogfejlődés újabb eredményeire is építő, öszszefoglaló jellegú egyetemi tananyagának ismertetése. Komplex módon tárgyalja az állam- és jogtudományok fogalmát, rendszerét, az egyes jogbölcseleti irányzatokat, bemutatja a norma fogalmát, a jogforrásokat, a jogrendszerek típusait. A jogalkalmazás számára hasznos elméleti alapokról szóló értekezést a jog érvényesüléséről és a jog hatékonyságáról szóló fejezetek jelentik, míg az államelmélet iránt érdeklődők a politikai rendszerekröl, az állam fogalmáról, az államok rendszerezésére törekvő elméletekről szóló fejezetekben olvashatnak a témáról részletes elemzést. (G. A.)

\section{JOGTÖRTÉNET, RÓMAI JOG}

- Szilágyi Dezső és müve

ANTAL Tamás

(Sorozat: Jogtörténeti Tár, ISSN 1417-877X; 4.) 
lurisperitus Kiadó, Szeged, 2016

Monográfia és forrásközlés. Terjedelem: 556 . Bibliográfia a lábjegyzetekben. ISBN 9786155411465

- A szerző a Szegedi Tudományegyetem Állam- és Jogtudományi Karának oktatója. A több mint ötszáz oldalas mủ a hajdani politikus, igazságügy-miniszter, jogtudós és egyetemi oktató emléke előtt tiszteleg, bemutatva életét és munkásságát. A kötet szerkezeti felépítése logikus és jól áttekinthető: először Szilágyi Dezső életét tekinti át, majd forrásokat közöl tőle a tanulmányaiból és egyetemi előadásaiból, valamint politikai jegyzeteiből. A kötet egyik legérdekesebb része Szilágyi Dezső büntetőjogi előadásainak közlése, amelyeket az egykori hallgatók kéziratos jegyzetei nyomán rekonstruált a szerző. A jegyzetek segítségével az olvasó képet kaphat Szilágyi Dezső szakmai nézeteiröl, illetve betekintést nyerhet a dualizmus korának jogászképzésébe is. (D. V.)

- A magyar jogtörténet válogatott bibliográfiája, 1560-1860

Bathó Gábor-Losonczi Eszter (szerk.)

(Sorozat: Állam- és Jogtörténeti Bibliográfiák, ISSN 0231-2026; 17.)

ELTE, Budapest, 2016

Bibliográfia. Terjedelem: 142.

- A bibliográfia összeállítói az NKE és az ELTE munkatársai. Kötetükben jogágak szerint felosztva találjuk a Habsburg-korszak címben megjelölt időszakában megjelent fontosabb múvek bibliográfiai jegyzékét. A mú elején egy rövid írás olvasható a magyar jogi szaknyelv kezdeteiröl, majd ezt követik a bibliográfiai jegyzékek. A föbb jogterületeken (alkotmányjog, büntetőjog, jogtörténet) kívül egyes különös jogterületek bibliográfiai jegyzékét is megtalálhatjuk: így az igazságügyi orvostan, a jogi nyelv, a katonai, az egyházi és parlamenti jog területére tartozó fontosabb művek listáját is. A könyv tehát nagyszerủ segítséget nyújt a jogtörténettel foglalkozó kutatóknak, témájuk hazai szakirodalmának feldolgozásához, a könnyebb kereshetőséget pedig a könyv végén helyet kapott névmutató segíti. (Sz. Zsa.)

- Ut juris ordo exigit: ünnepi tanulmányok Kajtár István 65. születésnapja tiszteletére Béli Gábor-Korsósné Delacasse Krisztina-Herger Csabáné (szerk.)

Publikon, Pécs, 2016

Tanulmánykötet. Terjedelem: 325. Bibliográfia a lábjegyzetekben. ISBN 9786155457692

- A tanulmányok szerzői a hazai jogi karok jogtörténeti tanszékeinek jelenlegi és korábbi vezetői, emellett gyakorló jogászok, Kajtár István jogi kari professzortársai és pályatársai, hazai és külföldi jogtörténészek, az ünnepelt barátai és tanítványai. A kötetben 30 különálló tanulmány olvasható, elsősorban jogtörténeti tárgyúak, de néhány aktuális kérdéssel foglalkozó írás is megtalálható. A tanulmányok közt magánjogiak és a közjog tárgykörébe tartozók is megtalálhatóak, így többek között olvashatunk Angyal Pál munkásságáról, a Praxis Criminalis szegedi boszorkányperekre gyakorolt hatásáról, a választottbíráskodás kezdeteiről, az egészség- és szegényügyi igazgatás kezdeteiröl, vagy például - Kajtár István előtt szakmai hobbijának, a tengerészeti jognak felidézésével tisztelegve - az 
itáliai flotta katonáinak jogállásáról is. A tanulmányokat a bőséges lábjegyzet és forrásmegjelölés teszi igazán színvonalassá. (Sz. Zsa.)

- Antecessores luris Romani: Óriás Nándor és Benedek Ferenc emlékezete. Tanulmányok a római jog és a jogtörténet köréből

Bíró Zsófia-Jusztinger János-Pókecz Kovács Attila (szerk.)

(Sorozat: Publicationes Cathedrae luris Romani Quiqueecclesiensis, ISSN 20647328; 4.)

PTE ÁJK Római Jogi Tanszék, Pécs, 2016

Tanulmánykötet. Terjedelem: 247. Bibliográfia a lábjegyzetekben.

ISBN 9789634291077

- A tanulmányok szerzői egyetemi oktatók, illetve az Óriás Nándor Szakkollégium Elmélettörténeti Tagozatának joghallgatói, tudományos diákkörösei. A szerzői kör annak jelzésére is szolgál, hogy a pécsi jogi kar mindkét hajdani professzora, Óriás Nándor és Benedek Ferenc is nagy hangsúlyt fektetett a tudományos utánpótlás-nevelésre. A könyv három nagy egységre tagolódik: az első fejezetben a címadók élet- és pályarajzait olvashatjuk. A tényszerủ leírás mellett személyes visszaemlékezések is színesítik ezeket az írásokat, amelyek végén a profeszszorok szakirodalmi munkásságának adatai is megtalálhatók. A második nagy fejezetben öt tanulmányt olvashatunk a római jog köréböl, amelyek a vállalkozási szerződés római jogi szabályaival, a büntetőjogi dogmatika előképeivel, a haszonélvező deliktuális védelmével foglalkoznak. A harmadik nagy fejezetben pedig a jogtörténet köréböl olvasható hat tanulmány, többek között a Szent Korona jelentőségéről, illetve az oktatás- és egyházpolitika kapcsolatáról. (Sz. Zsa.)

\section{- 120 éves az lgazságügyi Palota}

Bódiné Beliznal Kinga

(Sorozat: Bibliotheca Curiae, ISSN 2064-9525)

HVG-ORAC Lap- és Könyvkiadó Kft., Budapest, 2016

Monográfia. Terjedelem: 120. Bibliográfia 116-118. és a lábjegyzetekben.

ISBN 9789632583075

- A mű szerzője az Eötvös Loránd Tudományegyetem oktatója, a Kúria Elnöki Tanácsadó Testületének tagja, a m. kir. Kúria történetének avatott kutatója és ismerője. E könyvét - amely illeszkedik a szerző utóbbi években végzett komplex felsőbíróság-történeti kutatásai sorába - az Igazságügyi Palota 120 éves fennállásának évfordulójára írta meg. A kötet első fejezetében rövid ismertetőt olvashatunk az Igazságügyi Palota épületének történetéröl, építési előzményeiről, olyan kérdésekre választ kapva, hogy milyen érvek szóltak a Budán vagy Pesten való elhelyezéshez, vagy indokolt-e minden bírósági szintnek a külön épület. A fejezetet a korabeli képek teszik színesebbé. Ezután sorra veszi a Magyar Királyi Kúria 1896-ban müködő személyzetét, így az első elnök, másodelnök, tanácselnökök, bírák, és egyéb dolgozók hosszabb-rövidebb életrajzait olvashatjuk. Szakmai életútjuk ismertetése mellett a tisztviselők személyes történetei is helyet kaptak, a beszámolók alapján az olvasó képet kaphat a korabeli bírói szerepfelfogásról és a társadalmi elvárásokról is. (Sz. Zsa.) 
- Akiknek nevét emléktábla őrzi

Bódiné Beliznai Kinga-Zinner Tibor (szerk.)

(Sorozat: Bibliotheca Curiae, ISSN 2064-9525)

HVG-ORAC Lap- és Könyvkiadó Kft, Budapest, 2016

Emlékkönyv. Terjedelem: 275. Bibliográfia: 269-274. ISBN 9789632583044

- A kötet az 1956-os forradalom és szabadságharc hatvanadik évfordulójához kapcsolódik. A Legfelsőbb Bíróság azon bíráinak állít emléket, akik támogatták a forradalmat, vagy megtagadták a megtorlásban való részvételt. Annak idején a pártvezetés csak nagy nehézségek, komoly tisztogatások után találta meg azokat a bírákat, akik hajlandóak voltak részt venni a megtorlásban. Többen ugyanis inkább lemondtak tisztségükről, és vállalták karrierjük félbeszakítását, minthogy megszegjék hivatásuk íratlan szabályait. A kötet huszonhárom olyan bírónak állít emléket, akik nem vállalták az együttműködést a forradalmat leverő hatalommal: fejezetenként mutatja be életüket és munkásságukat. A könyv nagy erénye adatgazdagsága és tudományos igényessége: az egyes fejezetek gazdagon lábjegyzeteltek, a kutatás széles körben támaszkodik levéltári forrásokra. (D. V.)

- Válogatás a modern magyar honvéd-katonai büntető joghistória forrásaiból (1945-1949) II.

Farkas Ádám-Kelemen Roland (szerk.)

Széchenyi István Egyetem Batthyány Lajos Szakkollégium, Győr, 2016

Jogszabálygyüjtemény. Terjedelem: 211. Bibliográfia nincs.

ISBN 978615539175 0, 9786155391767 (online)

- A kötet szerkesztői a Széchenyi István Egyetem oktatói. E könyvük előzménye a Válogatás a modern magyar honvéd-katonai büntető joghistória forrásaiból, 1867-1945 címü könyv I. és II. kötete, amely 2014-ben jelent meg Farkas Ádám szerkesztésében, a második világháború utáni forrásokkal foglalkozó munka első kötete pedig 2015-ben látott napvilágot. Utóbbi könyvek célja az, hogy megismertessék az olvasót azokkal a jogforrásokkal, amelyek meghatározták az 1945 és 1949 közötti magyar katonai büntetőjogot és igazságszolgáltatást, ezáltal ösztönözni és támogatni kívánják a katonai büntetőjog modern kutatásait. A munka hiánypótlónak tekinthető, hiszen az általános jogi szaktudás kevésbé koncentrál a katonai büntetőjog dogmatikai tartalmára és rendszerére. (D. V.)

- Befordítva. Levéltári iratok a jogpolitikáról, a bíróságokról és a bíráskodás lehetőségeiről a „Kádár” korszakban (1958-1990)

GYEKICZKY Tamás

(Sorozat: Polgári Eljárásjog, ISSN 2498-5651; 2.)

Patrocinium, Budapest, 2016

Monográfia. Terjedelem: 225. Bibliográfia a lábjegyzetekben. ISBN 9789634130673

- A szerző gyakorló bíró, egyetemi oktató, szociológus végzettséggel, történeti érdeklődéssel és jelentős kutatási tapasztalattal. Kötete az osztályharcos szemléletű szocializmus jogi térhódítását mutatja be, elsősorban a levéltári forrásbázis alapján. Munkája folytatása a 2006-ban megjelent Helyzetjelentés: Levéltári ira- 
tok polgári eljárásjogunk történetéből I. (1951-1958) címü könyvének. Középpontjában a Kádár-korszak igazságszolgáltatása, azon belül a polgári eljárásjog új rendszerének kialakítása áll, a jogpolitikai irányelvekkel, a társadalmi bíráskodással és az új munkaügyi bíráskodással együtt. A polgári eljárásjog a kiépülö Kádár-korszakot még nem, az 1968-tól kezdődő időszakot azonban már „érdekelte”, és az a „politikai boszorkánykonyha” egyik fő megjelenési formájává lépett elő. Az igazságszolgáltatás (a hatalom teljességének alapvető eszköze) „rendszerbe állítása" elsősorban az igazgatási szabályokon keresztül valósult meg. A „rendszerszerü” jelenségek bemutatása során a könyv kitekint az ügyvédi hivatás gyakorlásának lehetőségeire és korlátaira is. (B. J.)

- Lépéstánc. Perjogi reform az Új gazdaságirányitási Mechanizmus sodrában (Történeti-jogszociológiai tanulmány)

GYEKICZKY Tamás

(Sorozat: Polgári Eljárásjog, ISSN 2498-5651; 3.)

Patrocinium, Budapest, 2016

Monográfia. Terjedelem: 323. Bibliográfia a lábjegyzetekben. ISBN 9789634131274

- A szerző gyakorló bíró, egyetemi oktató, aki emellett szociológus végzettséggel, történeti érdeklődéssel és jelentős kutatási tapasztalattal is rendelkezik. E kötete - amint az Előszóban a szerző is írja - egyenes folytatása a Befordítva címü munkának. A könyv azért született, mert az előző, áttekintő kötetben nem volt lehetőség bővebben kifejteni az ún. Új Gazdaságirányítási Mechanizmus, azaz a szocializmusban a hatalom átadása nélkül megvalósult „uralmi formaváltás” hatásait a jogpolitikára, a közjogra és különösen a polgári perjogra. Ezért ebben a külön munkában kapott helyet a III. Pp-novella és a különleges perek tárgyalása. A szerző végigelemezte az új rendszer máig ható hagyatékait is: a magánjogi hagyományok újraélesztése, a jogászi professzió újrafelfedezése, a megújulás képessége és akarása a szerző szerint épp ennek köszönhető, a mai reformok a történelem e részéből magyarázhatóak. (B. J.)

- Emlékkönyv: A Veszprémi Királyi Törvényszék története, 1872-1945

JAGUDITS Katalin-NaGY Ibolya Adél

Veszprémi Törvényszék, Veszprém, 2016

Forráskiadvány. Terjedelem: 167. Bibliográfia a lábjegyzetekben és 160-163.

ISBN 9789631254358

- A könyv szerzői a Veszprémi Törvényszék munkatársai, akik korabeli bírósági iratok, újságcikkek, levéltári források alapján tárják elénk a Veszprémi Királyi Törvényszék történetét a 19. század végétől a 20. század közepéig. A könyv az Országos Bírósági Hivatal által meghirdetett bíróságtörténeti kutatások sorába tartozik. Bemutatja az önálló veszprémi igazságszolgáltatás kialakulását, a Veszprémi Törvényszék épületének történetét, a dualizmus korában kialakult állami bírósági szervezetrendszert, illetve hosszabb-rövidebb életrajzi adalékokkal vázolja a törvényszék egykori elnökeinek és bíráinak szakmai pályafutását. A szerzök sok helyen beépítették a szövegekbe az eredeti dokumentumok másolatait, korabeli képeslapokat, képeket, jogeseteket, így a munka - adatgazdagsága mellett - 
illusztratív és közérthető is, és valóban korhű képet mutat be a Veszprémi Törvényszék hajdani mindennapjairól, sajátosságairól. (Sz. Zsa.)

\section{- Jogi kultúrák Ázsiában: Kultúrtörténet, jogtudomány, mindennapok} JanY János

(Sorozat: PANTA - Pázmány Nemzetközi Tanulmányok, ISSN 2416-1438; 5.) Typotex Kiadó, Budapest, 2016 Monográfia. Terjedelem: 720. Bibliográfia 674-705. ISBN 9789632798820

- A mú szerzője Kelet-kutató és jogtörténész, a Pázmány Péter Katolikus Egyetem oktatója. A könyvben egész Ázsia területére kiterjedő részletes ismertetőt olvashatunk nemcsak az egyes népek jogi kultúrájáról, állami berendezkedéséröl, hanem megismerhetjük a földrész népeinek szokásait, gondolkodásmódját. A mű hiánypótló jellegü, az ázsiai országok egyre növekvő globális jelentőségének figyelembevétele mellett a földrész jogtörténetének objektív szempontú összefoglalása jelentős érdeklődésre tarthat számot. A szerző a könyv egyes fejezeteiben kultúránként veszi sorba, többek között a zsidó, perzsa, iszlám, hindu, kínai, japán jog kialakulásának történeti körülményeit, a föbb jogintézményeket, államszervezeti megoldásokat, illetve egyes jogterületeket - például büntetőjog, házassági jog - is részletesen bemutat. Így a mú kiváló alapja lehet összehasonlító jellegü tanulmányoknak. (Sz. Zsa.)

- Szokásjog és jogszokás I-II.

Nagy Janka Teodóra (szerk.)

(Sorozat: Jogi Kultúrtörténeti, Jogi Néprajzi Kiskönyvtár, ISSN 2064-888X; 2.)

PTE, Kultúratudományi, Pedagógusképző és Vidékfejlesztési Kar, Szekszárd, 2016 Tanulmánykötet. Terjedelem: 407. Bibliográfia a lábjegyzetekben.

ISBN 9789634290803

- A kötet a Jogi Kultúrtörténeti, Jogi Néprajzi Kiskönyvtár sorozatába illeszkedik. A sorozat célja, hogy bemutassa a Tárkány Szücs Ernő Jogi Kultúrtörténeti és Jogi Néprajzi Kutatócsoport kutatási eredményeit. A kötet alapjául egy 2014-es szekszárdi interdiszciplináris konferencia szolgált, amelyen a kötet jogtörténész, történész, néprajzkutató, egyetemi oktató szerzői adtak elő. A kötet tematikáját tekintve valóban interdiszciplináris, a témákat a sokszínüség jellemzi. A bírói uniformis történetétöl kezdve a női törvényes öröklésen át számos izgalmas tanulmányt olvashatunk. A könyv megjelentetéséhez anyagi forrásokkal a jogi néprajzi digitális adattár létrehozására elnyert OTKA kutatás is hozzájárult. A kötet kiváló példája annak, hogy hogyan lehet izgalmas és olvasmányos módon vegyíteni a (jog)történetet a néprajztudománnyal. (D. V.)

- Rex et regnum - Tanulmányok a magyar politikai gondolkodás és kormányzás történetéből

RÁcz Lajos

(Sorozat: Florilegium, Series lurisprudentiarum ac Politicarum, ISSN 2498-7603; 1.) Gondolat Kiadói Kör, Budapest, 2016

Tanulmánykötet. Terjedelem: 404. Bibliográfia: 397-407. ISBN 9789636936822 
- A szerző egyetemi oktató, jogtörténész. Kötete olyan tanulmányokat ad közre három részben, amelyek túlnyomó többsége az 1980-2014 közötti negyedszázadban született és jelent meg jogtörténeti tankönyvekben, tanulmánykötetekben, illetve szakmai folyóiratokban. Az összeállítás apropóját egy, a győri Széchenyi István Egyetem által koordinált, részben történeti, részben hatályos közjogi tematikájú kutatás adta, amelyben a szerző külső kutatóként vett részt. A könyv első része államelméleti (pl. az alkotmánygondolat kialakulásával foglalkozó), a második rész államtörténeti témakörökkel (a kormányzás és közigazgatás bizonyos korszakokban, pl. a honfoglalás korában, a XV. században, az abszolutizmusban, az Erdélyi Fejedelemségben vagy a Monarchiában), végül a harmadik rész a közjog szimbólumaival (a szimbólumrendszer nomád gyökereivel, a címerrel, a Szent Koronával vagy a temetkezési szimbólumokkal) foglalkozik. Ebben a szerkezetben pedig az eredetileg önálló tanulmányok a közjogtörténet érdekességeit tárgyaló, egységes egésszé állnak össze. (B. J.)

- A kincstalálás római jogi, jogtörténeti és modern jogi kérdésköre

SIKLÓSI Iván

Patrocinium Kiadó, Budapest, 2016

Monográfia. Terjedelem: 211. Bibliográfia: 192-200. ISBN 9789634130949

- A könyv szerzője az Eötvös Loránd Tudományegyetem oktatója, aki komplex jelleggel mutatja be az egyik tulajdonszerzési módot, a kincstalálást: részletesen, jog-összehasonlító módszerrel ismerteti a kincstalálás föbb római jogi csomópontjait, a középkori és újkori jogtörténet, valamint a modern jogok megoldásait. Legrészletesebben a római jogi szabályokat tárgyalja: a korabeli források alapján ismerteti a kincstalálás definícióját, majd az egyes korszakok kincstalálásra vonatkozó szabályairól, a kincstalálás körében felmerült elméleti jogi problémákról, illetve konkrét esetekről olvashatunk. Az ezt követő fejezetekben az egyes államok jogi megoldásait mutatja be aszerint csoportosítva, hogy a szabályozás a római jog tovább élésén alapul-e (ilyen a francia, osztrák, német, brazil megoldás), vagy pedig nem a római jog tovább élését mutatja (így a svájci és a magyar szabályok). Végül pedig az angol és az amerikai szabályozásról olvashatunk egy-egy rövid ismertetőt. (Sz. Zsa.)

- A közjogi provizórium (1920-1944) időszakának alkotmányos berendezkedése I. Schweitzer Gábor-Szabó István (szerk.)

(Sorozat: A Pázmány Péter Katolikus Egyetem Jog- és Államtudományi Karának Könyvei, ISSN 2061-7240; 34)

Pázmány Press, Budapest, 2016

Tanulmánykötet. Terjedelem: 198. Bibliográfia a lábjegyzetekben.

ISBN 9789633082683

- A kötet nyolc tanulmányt tartalmaz, amelyek szerzői egyetemi oktatók; az alkotmány- és jogtörténet, valamint a történettudomány müvelői. A tanulmányok témájukat tekintve meglehetősen változatosak, de valamennyi az 1920 és 1944 közötti időszakot vizsgálja tematikus kötöttségek nélkül. A kötet tartalmaz szövegeket a törvényhatósági jogú városok szabályrendelet-alkotásáról, a Kúria döntvény- 
alkotási jogáról, a választójogról, illetve a szokásjog és a törvény viszonyáról is. Mivel az egyes tanulmányok mind gazdagon lábjegyzeteltek, a kötet forrásgyüjtés szempontjából is hasznos segítség lehet. (D. V.)

\section{KÖZIGAZGATÁSI JOG}

- A közigazgatás változásairól Magyarországon és Európában a rendszerváltástól napjainkig

BALÁZs István

Debreceni Egyetem, Debrecen, 2016

Kézikönyv. Terjedelem: 246. Bibliográfia: 244-246. ISBN 9789633186084

- A szerző a Debreceni Egyetem Állam- és Jogtudományi Karán tanszékvezető egyetemi tanár, az MTA Társadalomtudományi Kutatóközpont Jogtudományi Intézetének tudományos fömunkatársa. Munkájában arra vállalkozik, hogy ismerteti az elmúlt 25 év legfontosabb változásait és azok hatásait a közigazgatásban. A munka két nagyobb szerkezeti egységből áll. Az első rész a magyar közigazgatásban a rendszerváltástól 2010-ig lezajlott legfontosabb változásokat veszi sorra, valamint ezeknek a jelenlegi állapottal fennálló összefüggéseit ismerteti. A második rész az Európai Unió 12 tagállamának struktúráját mutatja be. A könyv számos statisztikai adatot, táblázatot és ábrát tartalmaz a levont következtetések, megállapítások szemléltetésének elősegítésére. A kötetet haszonnal forgathatják gyakorló jogászok és elméleti szakemberek egyaránt. (K. K. E.)

- Közigazgatási jog. Általános rész III. (A közigazgatási jog elméleti kérdései, a közigazgatási hatósági eljárásjog, a közigazgatási szankció)

Fazekas Marianna (szerk.)

(Sorozat: ELTE Jogi Kari Tankönyvek, ISSN 2060-6494)

Változatlan utánnyomás, ELTE Eötvös Kiadó, Budapest, 2016

Tankönyv. Terjedelem: 348. Bibliográfia a fejezetek végén.

ISBN 9789633121771

- Az eredeti, 2013-as kiadás annotációja a Pro Futuro 2015/1. számában olvasható. (V. B.)

- Régiók Európában. Adminisztratív struktúrák és területi identitás Elisabeth Károlyi (szerk.)

Károlyi J. Alapítvány, L'Harmattan, Budapest, 2016

Konferenciakiadvány. Terjedelem: 292. Bibliográfia: 273-292.

ISBN 9789634141235

- A könyv a 2015. március 13-14-én, Fehérvárcsurgón megrendezett nemzetközi konferencia 17 előadásáról készült utókiadvány; felépítése követi az előadások sorrendjét. A konferencia központi témáját az Európai Unióban zajló regionális törekvések adták. Ezzel összefüggésben a konferencia által felvetett kérdések között szerepel, hogy a regionális törekvések mennyiben sértik az Európai Unió felépítését és az egyes nemzetek identitását, mi a regionális hatóságok szerepe, 
hogyan alakul az önkormányzatok és a régiók kapcsolata, továbbá a regionális folyamatokban milyen szerepet tölt be az Európai Unió Régiók Bizottsága? Az elöadások a következtetések között foglalkoztak azzal is, hogy vannak-e mintaként szolgáló nemzeti megoldások, és ha igen, akkor azok mennyiben követendőek. A kiadvány hasznos információkkal szolgálhat a regionalizáció jelenlegi helyzetéröl és várható, jövőbeni alakulásáról is. (K.K. E.)

- A Magyarország helyi önkormányzatairól szóló törvény magyarázata Nagy Marianna-Hoffman István (szerk.) Harmadik, hatályosított kiadás, HVG-ORAC, 2016 Kommentár. Terjedelem: 610. Bibliográfia: 601-605. ISBN 9789632583112

- A kötet szerzői egyetemi oktatók, akik a Magyarország helyi önkormányzatairól szóló 2011. évi CLXXXIX. törvény (Mötv.), valamint az ehhez kapcsolódó jogszabályi rendelkezések értelmezéséhez nyújtanak segítséget a kötettel. A hatályosított változat elkészítése a 2014 óta bekövetkező jogszabályváltozások miatt vált szükségessé. A mű a fővárosi önkormányzat reformja, az önkormányzati feladatokat érintő módosítások, valamint az önkormányzatok gazdálkodásának változása miatt érintett rendelkezések magyarázatát is tartalmazza. A jogszabály értelmezésén túl az önkormányzati jog gyakorlatát is igyekszik bemutatni a legújabb eseteken, döntéseken keresztül. A második kiadás annotációját lásd a Pro Futuro 2016/2. számában. (J. V.)

\section{- Európai közigazgatás}

Torma András (szerk.)

A 2012-es első kiadás harmadik utánnyomása, Miskolci Egyetem, Miskolc, 2016 Tankönyv. Terjedelem: 257. Bibliográfia: 251-257. ISBN 9786155216350

- A munka 2012-es kiadásának annotációja a Pro Futuro 2014/2. számában olvasható. (K. K. E.)

- Közigazgatási jog. A helyi önkormányzatok és a Kormány általános hatáskörü területi államigazgatási szerve, a közigazgatási hatósági eljárás

Tóth András (szerk.)

(Sorozat: Jogi Szakvizsga Könyvek)

Patrocinium, Budapest, 2016

Tansegédlet. Terjedelem: 333. Bibliográfia nincs. ISBN 9789634130925

- A szerzők valamennyien egyetemi oktatók. A kötet két részre oszlik: egyrészt a helyi önkormányzatokra, másrészt a közigazgatási hatósági eljárásra vonatkozó tananyagra. Elöbbi fejezeten belül a szerzők egy alfejezetet a fővárosi és megyei kormányhivataloknak, járási hivataloknak és a kormányablakoknak is szántak. A kötet nem terjeszkedik túl a Mötv. bemutatásán, elméleti fejtegetéseket, nemzetközi kitekintést nem tartalmaz, célja a hatályos magyar joganyag megismertetése. A hatósági eljárásról szóló fejezet is a korábbi általános hatósági eljárásjogi törvényünk, a Ket. felépítését követi. Ennek megfelelöen kitér az elsőfokú eljárásra, a jogorvoslatok elemzésére és a végrehajtási eljárás specialitásainak bemutatására. A jogszabályhoz kapcsolódóan az elektronikus ügyintézés témaköre külön 
alfejezetet kapott. Az ismeretek befogadását a fejezetek végén található ellenőrző kérdések segítik. (V. B.)

\section{MUNKAJOG}

- Issues of digital workplace: the situation in Hungary

BANKó Zoltán-SzőKE Gergely László

JurInfo, Pécs, 2016

Szakkönyv. Terjedelem: 129. Bibliográfia: 112-129. ISBN 9789631275964

- A szerzők a munkajog, a közigazgatási és informatikai-adatvédelmi jog területén tevékenykedő egyetemi oktatók. Könyvükben az információs technológia fejlődésének a munkaeröre és foglalkoztatásra gyakorolt hatásait tárgyalják. A részletes elemzés nemcsak az információs társadalomról szóló klasszikus jogirodalomra támaszkodik, hanem új források felhasználásával kísérletet tesz a legfrissebb munka- és közigazgatási jogi tendenciák feltárására és bemutatására is, a folyamatosan felmerülö, már megoldott és még megoldatlan kihívások prezentálásával egyidejüleg. Bár a könyv elsősorban a munka és a foglalkoztatás jogi dilemmáira koncentrál, nemcsak a munkajogi szempontokat jeleníti meg, hanem azon kívüli kérdésköröket is górcső alá vesz, például a munkavállalók felügyelete és ellenörzése szabályozásának adatvédelmi jogi kereteit, továbbá az elektronikus dokumentumok hitelességével kapcsolatos ellentmondásokat. A tudományos következtetések mellett a szerzők de lege ferenda javaslatokat is megfogalmaznak a jogalkotó számára. (B. Á. P.)

\section{- A közalkalmazottak jogállásáról szóló törvény és magyarázata}

CsÉFFÁn József

Szegedi Rendezvényszervező Kft., Szeged, 2016

Kommentár. Terjedelem: 1003. Bibliográfia nincs. ISBN 9786155112102

- A szerző egyetemi oktató, kollégiumvezető bíró. A könyv egy korábbi változat átdolgozása a 2016. január 1-jén hatályos jogszabályoknak megfelelően. Tartalmazza a Munka Törvénykönyve, a közalkalmazottak jogállásáról szóló törvény és a kapcsolódó jogszabályok hatályos szövegét, a hozzájuk füzött magyarázatokat, a bírósági ítélkezés iránymutató eseti döntéseit, a Legfelsőbb Bíróság Munkaügyi Kollégiumának állásfoglalásait. Gyakorló jogászoknak, humánpolitikai szakembereknek tudományos igényességgel nyújt gyakorlati segítséget a közalkalmazotti jogviszony szabályainak alapos ismeretéhez és alkalmazásához. A korábbi kiadás annotációja a Pro Futuro 2016/1. számában olvasható. (P. Á.)

- Vezetök és beosztottak a magyar közigazgatásban

FÁBIÁn Adrián

Második, átdolgozott kiadás. Dialóg Campus Kiadó, Budapest-Pécs, 2016 Tankönyv. Terjedelem: 175. Bibliográfia: 165-175. ISBN 9786155376917

- A könyv bemutatja a magyar közigazgatás személyi állományát, a személyzeti rendszer belső összefüggéseit, a vezetők és beosztottak közötti jogi és nem jogi 
kapcsolatokat. Egy gyorsan változó világról ad pillanatképet, mégis azzal a céllal, hogy időtálló összefüggésekre világítson rá, hiszen a közigazgatás hatékony müködésének tartóoszlopa a személyzet. A szerző alapvetően a magyar joganyagra és a háttérben húzódó összefüggésekre koncentrál, a közszolgálati kart a vezetők és beosztottak szerinti csoportosításban vizsgálja. A könyv elsősorban tankönyvként szolgál, azonban hasznos ismereteket nyújt a közszolgálati személyzeti rendszer iránt érdeklődő elméleti és gyakorlati szakemberek számára is. (P. Á.)

- Munkajog

Gyulavári Tamás (szerk.)

(Sorozat: ELTE Jogi Kari Tankönyvek, ISSN 2060-6494; 7.)

Harmadik, átdolgozott kiadás. ELTE Eötvös Kiadó, Budapest, 2016

Tankönyv. Terjedelem: 578 . Bibliográfia a fejezetek végén és a lábjegyzetekben. ISBN 9789633122075

- A kötet szerzői munkajogász szakemberek, egyetemi oktatók, ügyvédek és bírák. A tankönyv harmadik, átdolgozott kiadása a hatályos munkajogi szabályok bemutatásán túlmenően tárgyal jogelméleti kérdéseket, ismerteti a jogalkotás irányelveit, ugyanakkor kitér gyakorlati példákra és a releváns bírói ítéletekre, továbbá tartalmazza már az új Polgári Törvénykönyv hatálybalépésével kapcsolatos módosításokat is. A tankönyv egyetemi hallgatóknak készült, ennek megfelelöen érthetően és összegzően taglalja a munkajogi tudás megalapozásához szükséges ismeretanyagot. A korábbi kiadások annotációja a Pro Futuro 2015/1. és 2016/2. számában olvasható. (P. Á.)

- Ünnepi kötet Dr. Czúcz Ottó egyetemi tanár 70. születésnapjára Hajdú József (szerk.)

(Sorozat: Acta Juridica et Politica, ISSN 0563-0606, 79. Acta Universitatis Szegediensis, ISSN 0324-6523)

Szegedi Tudományegyetem Állam- és Jogtudományi Kar, Szeged, 2016

Tanulmánykötet. Terjedelem: 648 . Bibliográfia a tanulmányok végén.

ISBN 9789633064795

- A könyvben Czúcz Ottó professzor (korábban az Alkotmánybíróság majd az Európai Unió Törvényszéke tagja) munkássága elött a közeli kollégák, munkatársak, pályatársak és volt hallgatók (összesen hatvannégyen, köztük számos külföldi pályatárs) fejezik ki tiszteletüket. A kötetben szereplő magyar, angol, német és francia nyelvű tanulmányok tartalmukat tekintve - alkalmanként a közös pályaszakaszt illető, személyes szálakkal átszőve - túlnyomó részben kapcsolódnak az ünnepelt szociális, illetve munkajogi munkásságához (pl. a nyugdíjbiztosítás, a hátrányos helyzetűek foglalkoztatása, a magyar munkajog elektronikus dokumentumai témakörében). Emellett több jogtörténeti, Európa-jogi, nemzetközi jogi, közigazgatási jogi tárgyú tanulmányt is olvashatunk (pl. az alapjogok érvényesüléséről az EU-ban, az európai közigazgatási térségről, a hatósági ügyek szolgáltatásként való értelmezéséről vagy a tartási szerződés történeti alapjairól). A kötetet a hagyományoknak megfelelöen az ünnepelt tudományos közleményeinek jegyzéke zárja. (P. Á.) 
- Társadalombiztosítási jog: jogi szakvizsga felkészítő kötet

Homıcskó Árpád Olivér

(Sorozat: Jogi Szakvizsga Könyvek)

Patrocinium, Budapest, 2016

Tansegédlet. Terjedelem: 213. Bibliográfia az egyes fejezetek végén.

ISBN 9789634131205

- A szerző a munka- és szociális jog területén tevékenykedő oktató és gyakorló jogász. A könyv - ahogy a címe is mutatja - a jogi szakvizsgára készülő jogászok számára készült, és a felkészüléshez kíván segítségül szolgálni. A kötetet az lgazságügyi Minisztérium által kiadott hivatalos tételsor mentén írta meg, ezért szerkezete is a tételcímekhez igazodik. Az egyes tételeknél tematikusan rendezve jeleníti meg a vonatkozó joganyagot és alkotmánybírósági gyakorlatot is. A kötet célja - a felkészülés segítése mellett - egyrészt az, hogy átfogó ismereteket biztosítson a társadalombiztosítási jog témakörében, másrészt pedig rávilágítson az egyes kérdésekkel kapcsolatban jelentkező jogértelmezési és joggyakorlatban felmerülő problémákra is. (B. Á. P.)

- Dignity at work: employees' personality rights in the $21^{\text {st }}$ century

KaJTÁr Edit

(Sorozat: Pécsi Munkajogi Közlemények, ISSN 1789-7637, 6)

Utilitates, Pécs, 2016

Monográfia. Terjedelem: 217. Bibliográfia: 190-217. ISBN 9789634290896

- A szerző a munkajog és az emberi erőforrás-menedzsment területén tevékenykedő egyetemi oktató, jogász. A kötetben angol nyelven dolgozza fel a 21. századi munkajog legnagyobb kihívásaként jelentkező alapjogi és személyiségi jogi kérdéseket. A könyv szerkezete ennek megfelelően az egyes, vizsgált alapjogokhoz igazodik, így részletesebben elemzésre kerül például a diszkrimináció tilalma, ezen belül az életkor, nem, anyaság és várandósság, továbbá részletesebben a magánszféra védelméhez való jog és az adatvédelem. A szerző bemutatja a vonatkozó magyar, főként polgári jogi és munkajogi szabályozást és joggyakorlatot, emellett részletesen elemzi az uniós vívmányokat, az Európa Tanács dokumentumait, ennek megfelelően az Emberi Jogok Európai Bírósága és az Európai Bíróság gyakorlatát is, továbbá nemzetközi kitekintés is szerepel a múben. A szerző végül önálló fejezetben fejti ki álláspontját, és megoldási javaslatokat fogalmaz meg a jövő jogalkotása számára. (B. Á. P.)

\section{- A Munka Törvénykönyvének magyarázata}

Kardkovács Kolos (szerk.)

Harmadik, hatályosított kiadás. HVG-ORAC, Budapest, 2016

Kommentár. Terjedelem: 534. Bibliográfia a lábjegyzetekben. ISBN 9789632583082

- A szerzők ügyvédek, gyakorló jogászok. A kötet a 2012-es kiadás hatályosított és bővített változata, amely tartalmazza a 2012 óta bekövetkezett jogszabályi módosítások, jogalkalmazói tapasztalatok, a gyakorlatban felmerült értelmezési kérdések, valamint a korábban külön kötetben megjelentetett átmeneti rendelke- 
zések mellett az időközben hatályba lépett 2013. évi Polgári Törvénykönyv szabályozásához igazított magyarázatot és elemzést. A szöveg továbbra is az Mt. szerkezetét követi, amely feldolgozza a kapcsolódó bírói gyakorlatot. A jelenlegi, harmadik kiadás az előző kiadáshoz képest további két év tapasztalatait, főként az Mt. értelmezését segítő, egyre bővülö bírói gyakorlatot dolgozta fel. A kötethez CD-melléklet tartozik, amely a módosításokhoz igazított, szerkeszthető munkajogi iratmintákat tartalmazza. Az első kiadás annotációját lásd a Pro Futuro 2014/1., a második kiadás annotációját a 2016/2. számában. (B. Á. P.)

- Segédlet a munka törvénykönyvéhez.

Cséffán József (szerk.)

(Jelöletlen sorszámú, ismételt kiadás.) Szegedi Rendezvényszervező Kft., Szeged, 2016

Kommentár. Terjedelem: 126. Bibliográfia nincs. ISBN 9786155112119

- A kiadvány egységesen foglalja össze a Munka Törvénykönyvéröl szóló 2012. évi I. törvény 2016. január 1-jétől hatályos szabályait, és a Polgári Törvénykönyvről szóló 2013. évi V. törvénynek a munkaviszonyban is alkalmazandó szabályait. A kötet a Munka Törvénykönyve hatályos szövege mellett tartalmazza a kapcsolódó jogszabályokat, a rendelkezésekhez füzött magyarázatokat, a bírósági ítélkezés iránymutató eseti döntéseit, a Kúria kollégiumi állásfoglalásait, jogegységi határozatait, kollégiumi véleményeit, valamint az elvi határozatait is, amely gyakorlati segítséget is nyújt az olvasó számára. A kiadvány korábbi változatát a Pro Futuro 2014/1. számában annotáltuk. (S. B.)

- Segédlet a közalkalmazottak jogállásáról szóló törvényhez Cséffán József (szerk.) (Jelöletlen sorszámú, ismételt kiadás.) Szegedi Rendezvényszervező Kft., Szeged, 2016

Kommentár. Terjedelem: 239. Bibliográfia nincs. ISBN 9786155112126

- A könyv célja, hogy segítséget nyújtson a közalkalmazotti jogviszony keretében történő munkavégzésre vonatkozó szabályok értelmezésében. Ennek érdekében a kötet tartalmazza az Mt., a Kjt., a Ptk. közalkalmazotti jogviszonyban is alkalmazandó rendelkezéseit. Mindezeken túl tartalmazza a kapcsolódó jogszabályok hatályos szövegét, a hozzájuk füzött magyarázatokat, a bírósági ítélkezés iránymutató eseti döntéseit, a Legfelsőbb Bíróság Munkaügyi Kollégiumának állásfoglalásait, jogegységi határozatait, illetve a legfontosabb iratmintákat is. A kiadvány korábbi változatát a Pro Futuro 2014/1. számában annotáltuk. (S. B.)

\section{NEMZETKÖZI MAGÁNJOG}

- A nemzetközi gazdasági kapcsolatok joga

BÁnRÉVY Gábor

Tizenegyedik, javított kiadás. Szent István Társulat, Budapest, 2016

Tankönyv. Terjedelem: 230. Bibliográfia: 179-183. ISBN 9789632775999 
- A könyv szerzője a 2013-ban elhunyt Bánrévy Gábor professzor, aki a PPKE JÁK Nemzetközi Jogi Intézetének alapító vezetője, egyetemi tanára volt. A tankönyv újabb kiadását Szabó Sarolta aktualizálta, amely a korábbi kiadásokkal egyezően komplex képet ad a nemzetközi gazdasági forgalom jogi kereteiröl, nemzetközi és hazai feltételeiröl. A jogterület forrásainak tisztázása után részletesen megvizsgálja a különféle nemzetközi vonatkozású, gazdasági célú szerződéstípusokat, átfogóan mutatja be azok tárgyát és alanyait. (K. N.)

- Nemzetközi magánjog: Általános rész

BURIÁn László

(Sorozat: A Pázmány Péter Katolikus Egyetem Jog- és Államtudományi Karának Tankönyvei, ISSN 2062-0837)

Második, átdolgozott kiadás. Pázmány Press, Budapest, 2016

Egyetemi jegyzet. Terjedelem: 230. Bibliográfia nincs. ISBN 9789633082836

- A szerző a PPKE JÁK Nemzetközi Magánjogi Tanszékének tanszékvezető egyetemi tanára. Az egyetemi hallgatók számára készült jegyzet célja a nemzetközi magánjog mint önálló jogterület elméleti megalapozása, gyakorlatias megközelítéssel. A kötet hét fejezetben tárgyalja a nemzetközi magánjog alapkérdéseit, fogalmát, forrásait, a történeti aspektusokat, valamint a kollíziós szabályokat. Mindezeket a releváns nemzetközi szerződések és uniós rendeletek listáját tartalmazó függelék egészíti ki. A mủ a 2017-es kiadású Különös részi tankönyvvel képez egységet. A korábbi kiadást a Pro Futuro 2016/1. számában annotáltuk. (F. B.)

- A nemzetközi gazdasági kapcsolatok joga I-II. MoLnÁR István János

(Sorozat: Magister Kötetek, ISSN 2498-5430)

Második kiadás. Patrocinium, Budapest, 2016

Egyetemi jegyzet. Terjedelem: 149. (I.); 217. (II.) Bibliográfia: 148-149. (I.); 214-216. (II.) ISBN 9789634131052 (I.); 978-963-413-106-9 (II.)

- A szerző egyetemi oktató. A kétkötetes jegyzet a nemzetközi gazdasági kapcsolatok joga tárgy oktatásához készült. Az első kötet a nemzetközi gazdasági kapcsolatok elméleti alapjait és közjogát tárgyalja, áttekintve mind a multilaterális, mind az európai uniós szabályozást. A második kötet az új Polgári Törvénykönyv rendelkezései alapján mutatja be a nemzetközi gazdasági kapcsolatok magánjogi területét: a nemzetközi gazdasági kapcsolatok magánjogának forrásait, illetve az egyes szerződéstípusokat (többek között a technológiatranszfer- a franchise és a kooperációs szerződést). A jegyzet tárgyalja a külföldiek gazdasági célú letelepedésének témakörét is. A korábbi kiadás annotációja a Pro Futuro 2017/2. számában olvasható. (B. A.) 


\section{PÉNZÜGYI JOG}

- A sportjog közpénzügyi alapjai

Bartha Ildikó-Bordás Péter-Nagy Emilia-Varga Judit

Debreceni Egyetem Állam- és Jogtudományi Kar, Debrecen, 2016

Szakkönyv. Terjedelem: 152. Bibliográfia a fejezetek végén.

ISBN 9789631250978

- A szerzők egyetemi oktatók. A kötet a sport közösségi finanszírozásának alapjait, annak közgazdasági és közpénzügyi vetületeit mutatja be. A mű vezérgondolata, hogy a hatályos magyarországi szabályozás jellemző példája a feladatellátás állami szintre emelésének. Az ehhez felhasznált eszközök sokfélék és igen erőteljesek. A kötet célja a sportjog közpénzügyi vetületeinek minél szélesebb körü meghatározása és elemzése, így az államháztartási finanszírozás, az adópolitika, a beruházások ösztönzése, az állami vagyongazdálkodás, az Európai Unió politikáinak érvényesítése mind vizsgálat tárgyát képezi. A kötet nemcsak a szakterületi képzés felsőfokú hallgatóinak és a gyakorlati szakembereknek, de a társadalomtudományok szélesebb köre iránt érdeklődőknek is hasznos olvasmány lehet. (B. P.)

- Alkotmány és adójog

DEÁk Dániel

HVG-ORAC, Budapest, 2016

Monográfia. Terjedelem: 594. Bibliográfia: 569-585. ISBN 9786932582962

- A szerző egyetemi tanár, a pénzügyi jogtudomány kutatásának egyik jelentős hazai képviselője. A kötet témáját az a felismerés adja, hogy világszerte elismerik azt, hogy az adóztatást alkotmányos keretek közé kell illeszteni, az adózót pedig alkotmányos védelemben kell részesíteni. Ahogyan a szerző kiemeli, különösen hangsúlyossá válik az adójog alkotmányos szintű szabályozása akkor, amikor a társadalomban, úgy mint ma Magyarországon, nincs közmegegyezés nemcsak az adópolitika részleteiben, hanem az alkotmányos alapértékek tekintetében sem. A kutatás tárgya a magyar adózási gyakorlat összehasonlító és nemzetközi adójogi szempontú elemzése. A kötet szerkezete és tartalma három fő elméleti kérdés köré összpontosul, ezek az alkotmányos adójog dinamikája, statikája és az adójogi gyakorlat alkotmányos próbája. A mü kiemelhető újdonsága a nemzetközi szakirodalomban és gyakorlatban megjelenő legújabb szemléletmód és teória közvetítése. (B. P.)

- Kommentár a közbeszerzési törvényhez

Dezső Attila (szerk.)

Wolters Kluwer, Budapest, 2016

Kommentár. Terjedelem: 943. Bibliográfia: 913-919. ISBN 9789632955803

- A szerzők gyakorlati szakemberek, egyetemi oktatók, illetve a jogalkotásban részt vevő szakértők. A könyv a 2015. évi CXLIII. törvény, azaz az új közbeszerzési jogszabály által generált változásokat tekinti át, hogy segítséget nyújtson a jogalkalmazók számára. A hazai közbeszerzési reform indoka a vonatkozó európai uniós 
joganyag újraszabályozása, kiegészítése. Újraszabályozásának a célja egyrészt, hogy megfeleljen az európai jogalkotók 2014. február 26-án elfogadott klasszikus közbeszerzési szektorra, a vízügyi, energiaipari, közlekedési és postai szolgáltatási ágazatban müködő ajánlatkérőkre vonatkozó új irányelvcsalád követelményeinek, másrészt pedig az, hogy a hazai közbeszerzések során felhalmozott tapasztalatokat hatékonyan átültetesse a gyakorlatba. (L. D.)

\section{- Adótan}

HeRICH György

(Sorozat: Adó abc, ISSN 1426-8111)

Penta Unió, Pécs, 2016

Kézikönyv. Terjedelem: 453. Bibliográfia a lábjegyzetekben. ISBN 9786155249402

- A könyv az Adó abc Adótan kötetének huszonhetedik, átdolgozott kiadása. A huszonötödik kiadás annotációját lásd a Pro Futuro 2015/1. számában. (B. P.)

- Kézikönyv az önkormányzati vagyongazdálkodásról

Hoffman István (szerk.)

HVG-ORAC, Budapest, 2016

Kézikönyv. Terjedelem: 280. Bibliográfia: 271-274. és a lábjegyzetekben. ISBN 9789632583204

- A szerzők az ELTE, illetve a Debreceni Egyetem Állam- és Jogtudományi Karának oktatói. A kötet az önkormányzatok tágabb értelemben vett vagyongazdálkodásával összefüggő kérdéseket vizsgálja jogtudományi aspektusból. A mű két nagy szerkezeti egységre tagolódik. Az első részbe tartozó fejezetek az önkormányzati vagyon egészét érintő horizontális szabályokat tekintik át, míg a második rész fejezetei az egyes ágazati vagyonnal összefüggő rendelkezéseket vizsgálják. A kötet szerzői törekedtek a témával kapcsolatban felmerülő gyakorlati problémák bemutatására, és a kapcsolódó alkotmánybírósági, illetve felsőbírósági joggyakorlat áttekintésére. A kézikönyv egyaránt alkalmas az önkormányzati vagyongazdálkodással foglalkozó köztisztviselök, gazdasági társaságok munkavállalóinak, illetve a témával kapcsolatba kerülő egyéb szervezetek munkájának támogatására, ahogy a téma iránt érdeklődők kíváncsiságának kielégítésére is. (V. J.)

- A közbeszerzés joga: kommentár a gyakorlat számára

Patay Géza (szerk.)

HVG-ORAC Kft., Budapest, 2016

Kommentár. Terjedelem: 1062. Bibliográfia nincs. ISBN 9639203149

- A kommentár szerzői gyakorlati szakemberek, akik átfogó képet kívánnak adni a hazai közbeszerzés új szabályrendszeréröl, így nemcsak az új közbeszerzési törvényröl, hanem a végrehajtási jogszabályokról is. Emellett azon kérdéskörök esetében, ahol indokoltnak tartják, az uniós szabályozásra, az Európai Bíróság döntéseire, valamint a hazai joggyakorlatra is utalnak. Ezek alapján nemcsak az új szabályok hatásait tárják elénk, hanem a jogalkalmazás nehézségeit és javasolt megoldási lehetöségeket is bemutatnak. A könyv szerkezete az alábbiak szerint épül fel: a törvény általános rendelkezéseinek elemzését követően az uniós 
értékhatárt elérő értékü közbeszerzések szabályait, a nemzeti eljárásrendet, a közbeszerzési szerződéseket, majd a közbeszerzéshez kapcsolódó jogorvoslatokat tárgyalja, végül a Közbeszerzési Hatóságot mutatja be. A kiadvány elsősorban a közbeszerzéssel foglalkozó szakemberek gyakorlati munkáját kívánja segíteni. (L. D.)

\section{POLGÁRI JOG ÉS POLGÁRI ELJÁRÁSJOG}

- Hitelbiztositékok

Bodzási Balázs (szerk.)

(Új Magánjog sorozat; 13.)

HVG-ORAC, Budapest, 2016

Monográfia. Terjedelem: 879. Bibliográfia a lábjegyzetekben. ISBN 9789632583129

- A szerzők részben egyetemi oktatók, kutatók, részben gyakorlati szakemberek (több terjedelmes fejezet szerzője Leszkoven László, illetve maga a szerkesztő). A kötet a hitelbiztosítéki jog leggyakoribb intézményeit tekinti át. A hitelbiztosítékok részletszabályainak ismertetése érdekében elsőként az intézmény alapfogalmait, elméleti alapvetéseit mutatja be. Külön fejezetekben szól a fiduciárius hitelbiztosíték intézményéről, valamint az elidegenítési és terhelési tilalmakról. A kezesség, illetőleg a garanciaszerződés szabályai is átfogó elemzésre kerülnek a müben. A zálogjogi szabályozás áttekintése körében olvashatunk a zálogjog fogalmáról, a zálogkövetelésről, a zálogtárgyról, de a mú kitér az alzálogjog, az ingatlan-jelzálogjog, a kézizálogjog, valamint a törvényes zálogjog szabályaira is. A kötet külön fejezetet szentel a hitelbiztosítéki nyilvántartásnak, melyben részletesen bemutatja ezen intézményt, és megismerkedhetünk a regisztrációt, a bejegyzést, feljegyzést és törlést, valamint a jogorvoslati lehetőségeket szabályozó rendelkezésekkel. (K. N.)

- A fogyasztóvédelem közjogi keretei

BENCSIK András

(Sorozat: Dialóg Campus Szakkönyvek, ISSN 1417-7986; Institutiones Juris, ISSN 1218-9375)

Dialóg Campus, Budapest-Pécs, 2016

Monográfia. Terjedelem: 191. Bibliográfia: 181-191. ISBN 9786155376801

- A Szerző a Pécsi Tudományegyetem Állam- és Jogtudományi Karának oktatója. A monográfia legföbb célja, hogy feltérképezze a fogyasztóvédelem rendszerének hiányosságait, következtetéseket vonjon le, és javaslatokkal éljen a jogterület továbbfejlesztése érdekében. A szerző múvében az elméleti alapokon, valamint az intézményrendszeren túlmenően kiemelt figyelmet fordít a fogyasztóvédelem (hazai és nemzetközi) alkotmányi alapjainak vizsgálatára is. Tanulmányozza továbbá a fogyasztóvédelem jogérvényesítési rendszerét, ezen belül elemzi a békéltető testületek müködését, bemutatja azok szerepét, valamint részletes európai kitekintést is nyújt a téma kapcsán. (Sz. Zs.) 
- Elörelátható károk: az előreláthatósági korlát hatása szerződésszegési kártérítési jogunkra

CSÖNDES Mónika

ELTE Eötvös, Budapest, 2016

Monográfia. Terjedelem: 398. Bibliográfia: 377-392. ISBN 9789633122525

- A Szerző a Corvinus Egyetem oktatója. A kötet az előreláthatósági korlát jogtörténeti, jog-összehasonlító és jogdogmatikai elemzésére vállalkozik. A szerző felkutatja az előreláthatósági korlát intézményének forrásait, végigkíséri annak fejlődési állomásait, megvizsgálva a Ptk. előtti szabályozásokat. Az előreláthatósági klauzula alkalmazhatósága körében rámutat az előreláthatósági korlát és a kártérítési felelősség kapcsolatára, valamint a polgári jogi felelősségi szabályokon kívül a téma társasági jogi és munkajogi kárfelelősségi vetületeit is feltárja. A kötet záró témájaként a szerző vizsgálat tárgyává teszi az előreláthatósági korlát jelenleg hatályos kártérítési jogunkra gyakorolt hatását, e körben rámutatva az ítélkezési gyakorlatban és a szerződési jogi dogmatikában megjelenő hatásokra. (K. N.)

- A határokon átnyúló fizetésképtelenségi eljárások CsÖKE Andrea Második, átdolgozott kiadás. HVG-ORAC, Budapest, 2016 Kézikönyv. Terjedelem: 603. Bibliográfia a lábjegyzetekben. ISBN 9789632582979

- A szerző kúriai bíró. A mü első kiadása 2008-ban jelent meg, mely összefoglalta az Európai Bíróságnak a fizetésképtelenségi eljárásról szóló 1346/2000/EK rendelet szabályaihoz füzött értelmezéseit és ismertette a kialakított bírói gyakorlatot. A fizetésképtelenségi eljárásokról szóló 2015/848 rendelet felváltotta a korábbi EK rendelet szabályait, és 2017. június 26-tól alkalmazandó. A könyv átdolgozott kiadásában ezért a szerző elsőként arra vállalkozik, hogy összefoglalja a korábbi rendelet alapján kialakult bírósági gyakorlatot és jogszabály-értelmezési elveket. Másodsorban célja, hogy elemző módon bemutassa az új rendelkezéseket, amelyek tekintetében bírói szemmel vizsgálja meg az új szabályok alkalmazhatóságát, és ismerteti az egyes kérdések kapcsán megjelenő álláspontokat. (K. B.)

\section{- Ingatlanjog I.}

Fónyıné KaZARECZKı Andrea-Tolnal Ildikó

Wolters Kluwer, Budapest, 2016

Kézikönyv. Terjedelem: 516. Bibliográfia: 515-516. ISBN 9789632956398

- A mü szerzői bírák. A könyv első részében az ingatlanjog történetének bemutatása és elemzése jelenik meg. A szerzők elsőként az Aranybullától 1945-ig mutatják be az ingatlanjog fejlődését, az ingatlanjogot teremtő és formáló jogszabályokat. Ezt követően az 1959. évi IV. törvény (régi Ptk.), illetve a 2013. évi V. törvény (új Ptk.) vonatkozó szabályozását hasonlítják össze, és elemzik a kapcsolódó bírói gyakorlatot. A könyv második része egy ún. ingatlanjogi útmutató, mely rendszerezi az ingatlanjoghoz kapcsolódó fogalmakat és gyakorlatot, eligazít a hatályos eljárási rendben, az ingatlan-nyilvántartás szabályaiban, a közös tulajdon specialitásaiban. Mindkét szerző nagy hangsúlyt fektet a téma gyakorlati szempontú 
bemutatására, így a mü a gyakorlati szakemberek és a jogi oktatás számára is hasznos. (Sz. V.)

- Kié a pénzem? - A pénz dologi jogi vizsgálata

GÁRDOS István

Wolters Kluwer, Budapest, 2016

Monográfia. Terjedelem: 247. Bibliográfia: 245-246. ISBN 9789632955773

- A szerző ügyvéd. A monográfia témája a pénz, a vizsgálat tárgyát képező kérdések pedig elsősorban a dologi jog területéhez kapcsolódnak, emellett vannak kötelmi jogi vonatkozásaik is. A könyv célja, hogy felhívja a szakmai közvélemény figyelmét a pénzzel kapcsolatos kevésbé tisztázott kérdésekre és felkeltse az érdeklődést a pénz jogi sajátosságai iránt. A monográfia a pénz közgazdasági és jogi fogalmának áttekintésével kezdődik, majd vizsgálja a pénz feletti tulajdonjog megszerzésének különféle módjait és sajátosságait, valamint e tulajdonszerzésnek az idegen dologbeli jogokra gyakorolt hatását. A szerző a pénzletét közelebbi vizsgálatával bemutatja, hogy egy konkrét jogviszonyban miként müködnek a pénz feletti tulajdonjog és az azt terhelő korlátolt dologi jogok alakulásával kapcsolatban megfogalmazott elvek. A szerző kritikai észrevételeket és javaslatokat is megfogalmaz a jövőbeni jogalkotás számára. (B. E.)

- A törvény által elöírt közös jogkezelés a magyar és a francia szerzői jogban HaJdú Dóra

(Sorozat: Médiatudományi Könyvtár, ISSN 2063-5222; 26.)

Nemzeti Média- és Hírközlési Hatóság Médiatanács Médiatudományi Intézete, Budapest, 2016

Monográfia. Terjedelem: 235. Bibliográfia a lábjegyzetekben. ISBN 9786155302220

- A szerző egyetemi oktató. A könyv alapjául a szerző francia-magyar, kettős témavezetésű doktori disszertációja szolgált. Célja annak az érzékeltetése, hogy az eltérő kulturális, gazdasági, társadalmi és jogi hagyományokkal rendelkező magyar és francia államban milyen eltérő felfogással közelítenek a törvény által elöírt közös jogkezelés kérdéséhez. A szerző a közös jogkezelési esetköröket (a vezetékes továbbközvetítési jogot és a többszörözés engedélyezésére vonatkozó közös jogkezelést) - azok sokfélesége okán - rendszerben helyezi el, és megvizsgálja, hogy az egyes esetek milyen módon képezhetik a szerzői jogok érvényesülésének korlátját. A magyar és a francia szabályozás közös jogkezelési eszköztárának bemutatása mellett a vonatkozó joggyakorlat elemzésére is sor kerül a müben. (G. M.)

- A magyar fizetésképtelenségi jog kézikönyve JuHÁsz László

Hatodik, átdolgozott kiadás. HVG-ORAC, Budapest, 2016

Kézikönyv. Terjedelem: 1340. Bibliográfia: 1251-1253. ISBN 9789632583174 (l. kötet), 9786932583181 (II. kötet)

- A szerző táblabíró; egyetemi docens a PTE Állam- és Jogtudományi Karán. A kézikönyv hatodik kiadását a csődtörvény újabb módosítása tette szükségessé, ugyan- 
is az ötödik kiadás 2014. évi megjelenése után a felszámolási eljárásban hatályba lépett az adós vagyontárgyainak elektronikus értékesítéséről szóló 17/2014. (II. 3.) Korm. rendelet, továbbá új elemként jelent meg a Pp. elektronikus kapcsolattartásra vonatkozó szabályrendszere. A szerző a hatodik kiadásban az új jogintézmények és azok szabályozási összefüggéseinek bemutatása mellett az ötödik kiadásában még nyitott problémaként jelzett kérdésekről a már megújult bírói gyakorlat tükrében foglal állást, ismertetve a Kúria vonatkozó döntéseit. A könyv egyik korábbi kiadását a Pro Futuro 2012/2. számában annotáltuk. (K. B.)

\section{- Fájlcsere és felelösség}

KöHIDı Ákos

(Sorozat: Médiatudományi Könyvtár, ISSN 2063-5222; 25.)

Nemzeti Média- és Hírközlési Hatóság Médiatanács Médiatudományi Intézete, Budapest, 2016

Monográfia. Terjedelem: 202. Bibliográfia a lábjegyzetekben. ISBN 9786155302213

- A szerző ügyvéd. A könyv alapjául a szerző megvédett PhD-dolgozata szolgál. A leglényegesebb szerzői jogi, felelősségtani és a vonatkozó technológiával kapcsolatos alapfogalmak ismertetését követően a szerző az internetes fájlcserélő rendszerek használata során jelentkező jogsértésekkel és az ezekkel összefüggő felelősségi kérdésekkel foglalkozik. A könyv alapkérdése, hogy a polgári jogi felelősség mennyiben alkalmas eszköz az adott jogsértések kezelésére. Ennek körében elsősorban a kártérítési felelősség, emellett a kapcsolódó helytállási kötelezettségek vizsgálatára került sor. A felelősséget az okozati összefüggés skáláján a közvetettség felé haladva három fő logikai csomóponton - az egyéni felhasználók, a közvetítő szolgáltatók és más szolgáltatók, valamint az internetszolgáltató szintjén - vizsgálja. Elsősorban a magyar szabályozást ismerhetjük meg, de a szerző rövid áttekintést nyújt a német és a brit szabályozásról is. (G. M.)

- A magánjog általános tana

LÁBADY Tamás

Szent István Társulat, Budapest, 2016

Tankönyv. Terjedelem: 258. Bibliográfia: 255-258. ISBN 9789632774589

A 2014-es kiadás változatlan utánnyomása. A 2014-es kiadás annotációját lásd a Pro Futuro 2016/1. számában. (G. M.)

- Szerződésszegés a polgári jogban

LESZKOVEN László

Wolters Kluwer, Budapest, 2016

Monográfia. Terjedelem: 401. Bibliográfia a lábjegyzetekben. ISBN 9789632955834

- A szerző a Miskolci Egyetem Állam- és Jogtudományi Karának oktatója. A monográfia a szerződésszegés magyar polgári jogi szabályozását tekinti át, amely feladatot a Polgári Törvénykönyv szerződésszegésre vonatkozó közös szabályainak vizsgálatán keresztül végez el a szerző. A mű követi a kódex szabályozási rendszerét az intézmények bemutatása során, az elméleti alapvetést követően az egyes szerződésszegési szabályok feldolgozása jelenik meg. Így többek között 
elemzi az elállás, a késedelem, a hibás teljesítés és a termékszavatosság intézményét. A könyvben a szerző bírói döntések vizsgálatán keresztül kíván arra a kérdésre választ adni, hogy miként alkalmazhatóak az irányadó döntések az új Polgári Törvénykönyv megváltozott jogi környezetében. (G. M.)

- Jogkimerülés a szerzői jogban

Mezel Péter

(Sorozat: Médiatudományi Könyvtár, ISSN 2063-5222; 20.)

Nemzeti Média- és Hírközlési Hatóság Médiatanács Médiatudományi Intézete, Budapest, 2016

Tanulmánykötet. Terjedelem: 204. Bibliográfia: 175-204. ISBN 9786155302169

- A szerző a Szegedi Tudományegyetem Állam- és Jogtudományi Karának oktatója. E kötet a szerző korábban megjelent tanulmányainak továbbfejlesztése, komplex összefoglalása, amelyben a jogkimerülés érvényesülését több nemzeti jogrend megoldásainak tükrében vizsgálja. A dogmatikai alapok meghatározását követően az Európai Unió, valamint az Egyesült Államok szerzői jogának fejlődéséről és jelenleg érvényesülő szabályozásáról ad áttekintést. Részletesen vizsgálja a digitális jogkimerülés határait a két jogrendszer vonatkozásában, valamint ítéletek és jogesetek mélyreható elemzésével a terület joggyakorlatát is bemutatja. (Sz. Zs.)

- Az optimális szabadalmak elméletének kiterjesztései

NAGY Benedek

(Sorozat: Philosophiae Doctores, ISSN 2061-1315)

JATE Press, Szeged, 2016

Monográfia. Terjedelem: 140. Bibliográfia: 123-128. ISBN 9789633152911

- A szerző a Szegedi Tudományegyetem Gazdaságtudományi Karának oktatója. A könyv a szerző doktori értekezésére épül, amelynek témája a szellemi tulajdonjog védelmi rendszere, kifejezetten a szabadalmi védelem. A könyv fejezetei az elméleti megközelítést követően a magyarázó, értelmező megközelítést alkalmaznak (vizsgálva pl., hogy hogyan kapcsolódik az innováció a tudáshoz), majd elemző, értekező részek következnek. Itt foglalkozik azzal a kérdéssel is, hogy az optimális szabadalmak elméletére alkalmazható-e a kvázi-hiperbolikus diszkontálás. A szerző kitekintést tesz a szabadalmi oltalom nemzetközi modelljeinek világába is, s megállapításait ábrákkal, képletekkel támasztja alá. (Sz. Zs.)

\section{- Orvosi kártérítés}

PRIBULa László

(Sorozat: Bírói Gyakorlat Füzetek, 2063-725X; 20.)

Opten, Budapest, 2016

Kézikönyv. Terjedelem: 313. Bibliográfia a fejezetek végén. ISBN 9786155122361

- A szerző egyetemi oktató, kollégiumvezető bíró. Az elmúlt évtizedekben jelentősen növekedtek Magyarországon az egészségügyi szolgáltatókkal szembeni, kártérítés megfizetése iránt indított, polgári peres eljárások. E jogviták az általános polgári jogi kártérítési felelősségen alapulnak, azonban a jogalkalmazás 
figyelembe veszi a jogviszony sajátosságait. A könyv tizenhárom fejezetben, e sajátosságokra fókuszálva dolgozza fel az orvosi kártérítés témakörét. A szerző a hazai jogalkalmazás által kialakított gyakorlat segítségével, bírói döntéseken keresztül mutatja be többek között az orvosi kártérítési felelősség alapjait, a beteg kötelezettségeit, a szakértői bizonyítás egyes kérdéseit, illetve azokat a szempontokat, amelyek a vagyoni és a nem vagyoni kártérítés (sérelemdíj) összegének meghatározásánál irányadóak. (B. E.)

- Kommentár az európai fizetési meghagyásos eljárásról szóló rendelethez: Kommentár az európai fizetési meghagyásos eljárás létrehozásáról szóló, 2006. december 12-i 1896/2006/EK európai parlamenti és tanácsi rendelethez

RÁk Viktor

Wolters Kluwer, Budapest, 2016

Kommentár. Terjedelem: 375. Bibliográfia: 365-367. ISBN 9789632955728

- A szerző gyakorló jogász, a Magyar Országos Közjegyzői Kamara Jogi Irodájának helyettes vezetője. A munka az európai fizetési meghagyásos eljárás létrehozásáról szóló 1896/2006/EK európai parlamenti és tanácsi rendelet bemutatására vállalkozik, figyelemmel a rendelet hatálybalépése óta eltelt csaknem egy évtized európai bírósági és hazai joggyakorlatára. A kommentár erénye, hogy a rendelet egyes cikkei kapcsán - az európai fizetési meghagyásos eljárás létrejöttének történetét és a jogintézmény dogmatikai hátterét érintő elméleti jellegű megállapítások mellett - központi szerepet szán a már felmerült és a jövőben várhatóan felmerülő jogalkalmazási kérdések gyakorlati szempontú ismertetésének. (Sz. D.)

- Jogi személyek, gazdasági jog

Sándor István (szerk.)

(Sorozat: Jogi Szakvizsga Könyvek)

Patrocinium, Budapest, 2016

Tansegédlet. Terjedelem: 525. Bibliográfia nincs. ISBN 9789634130857

- A szerkesztő és a szerzők egyetemi oktatók, gyakorló jogászok. A könyv az Igazságügyi Minisztérium által a jogi szakvizsga letételére készülők számára kiadott hivatalos tételsor mentén íródott, és tematikusan rendezve tartalmazza az egyes témakörökhöz tartozó joganyagot és bírósági gyakorlatot. Célja, hogy átfogó ismereteket biztosítson többek között a jogi személyek, a gazdasági társaságok, a civil szervezetek, a csőd- és felszámolási eljárás, valamint a cégnyilvántartás témakörében, és rámutasson az egyes kérdésekkel kapcsolatban jelentkező jogértelmezési és joggyakorlatban felmerülö problémákra. (B. E.)

- Iparjogvédelem-intenzív szakágazatok Magyarországon

Simon Dorottya

Szellemi Tulajdon Nemzeti Hivatala, Budapest, 2016

Kézikönyv. Terjedelem: 112. Bibliográfia: 112. és a lábjegyzetekben.

ISBN 9789639157811

- A szerző a Szellemi Tulajdon Nemzeti Hivatal testületi tagja. Az iparjogvédelemintenzív ágazatok gazdasági súlyának összesítésére a hazai szakirodalomban 
eddig még nem került sor. A vizsgálat módszertani alapját egy, az Amerikai Egyesült Államokban elvégzett tanulmány képezi, a vizsgálat alapjául szolgáló adatokat a Szellemi Tulajdon Nemzeti Hivatala tette közzé. A szerző a módszertan részletes bemutatását követően külön fejezetekben elemzi a szabadalommal, a használatiminta-oltalommal, a formatervezésiminta-oltalommal, a védjeggyel kapcsolatos, szakágazatokra, valamint az iparjogvédelem-intenzív szakágazatokra vonatkozó adatokat. A fejezetek végén a hazai eredmények összevetésre kerülnek a releváns nemzetközi adatokkal is. (K. N.)

- Polgári eljárásjog

Udvary Sándor (szerk.)

(Sorozat: Jogi Szakvizsga Könyvek)

Második, átdolgozott kiadás. Patrocinium, Budapest, 2016

Tansegédlet. Terjedelem: 637. Bibliográfia nincs. ISBN 9789634131199

- A szerkesztő és a szerzők egyetemi oktatók, bírák, közjegyzők, többen a jogi szakvizsgabizottság tagjai. A kötet - témaköreiben igazodva a jogi szakvizsgabizottság által kibocsátott szakvizsgatételsorhoz - áttekinti a polgári eljárásjogi joganyagokat. A polgári eljárásjog területén bekövetkezett jogszabályváltozásokra tekintettel került sor a kötet átdolgozására, amelynek során a szakvizsgára készülőket a hatályos joganyag egy kötetben való megjelenítésével kívánták a szerzők segíteni. A mű szerkezete tagolt (17 fejezet), szemléletes jelzésekkel, ábrákkal, kiemelésekkel és utalásokkal 82 témát dolgoz fel. Az első kiadás annotációját lásd a Pro Futuro 2017/2. számában. (Sz. V.)

- Kommentár a polgári perrendtartáshoz: kommentár a polgári perrendtartásról szóló 1952. évi III. törvényhez

Wopera Zsuzsa (szerk.)

Wolters Kluwer, Budapest, 2016

Kommentár. Terjedelem: 1300. Bibliográfia: 1233-1259. ISBN 9789632955537

- A mű szerkesztője egyetemi tanár, szerzői egyetemi oktatók és gyakorlati szakemberek. A kommentár a polgári perrendtartásról szóló 1952. évi III. törvény (Pp.) normaszövegének elemzésén túlmenően bemutatja a polgári eljárásjog bírói gyakorlatát, a hazai vonatkozású uniós szabályozást, valamint az Emberi Jogok Európai Bíróságának ítélkezési gyakorlatát az észszerủ idő követelményét nem teljesítő polgári perek tekintetében. A kommentár feldolgozza továbbá a Pp. normaszövegébe 2015 áprilisában beiktatott XXI/A. fejezet képmáshoz és hangfelvételhez való jog érvényesítése iránt indított perekre vonatkozó szabályait, valamint a Kúriának a bírósági jogalkalmazást felülvizsgáló 2015. július 15-én kiadott 3/2015. Polgári jogegységi határozatát is. A kommentár a 2018. január 1-én hatályba lépett új polgári perrendtartás (2016. évi CXXX. törvény) mellett továbbra is jelentős, mivel az új törvény hatálybalépése elött indult perekben továbbra is az 1952. évi III. törvény és e kommentár által adott értelmezések alkalmazandóak. (K. B.) 